\title{
A BARREN PART OF THE MAIN?: THE VEGETATION OF HUNTER ISLAND, FLEURIEU GROUP, BASS STRAIT
}

\author{
by Stephen Harris and Eve Lazarus
}

(with one table, five text-figures, ten plates and three appendices)

Harris, S. \& Lazarus, E., 2002 (31:xii): A barren part of the main?: the vegetation of Hunter Island, Fleurieu Group, Bass Strait. Papers and Proceedings of the Royal Society of Tasmania 136: 107-126. https://doi.org/10.26749/rstpp.136.107

ISSN 0080-4703. Nature Conservation Branch, Department of Primary Industries, Water and Environment, GPO Box 44, Hobart, Tasmania 7001, Australia.

Hunter Island, visited over millennia by Aboriginal people and settled early in the nineteenth century by sealers and later by a succession of grazing lessees, has preserved in its vegetation pattern the effects of a long history of firing and clearing. The vegetation also reflects the substrate and topographic features of the island with a major dichotomy between the heaths and scrub on the highly acid quartzites that underlie most of the island, and woodlands and grasslands on the highly alkaline sands that are rafted onto its western part.

Eucalyptus viminalis occurs on alkaline sands on Hunter Island, in contrast to the absence of the species on calcareous coastal sands in the rest of its range in southeastern Australia. Heathlands make up 38\% and scrub $37 \%$ of the island. Other vegetation types recorded are swamp forests, button grass moorland, exotic and native grasslands, Eucalyptus viminalis woodland, wetlands, mutton-bird rookery vegetation and lichen-fields.

The flora has strong affinities with the northwestern coast of the Tasmanian mainland and a weaker affinity with Three Hummock Island, which is a granite island rather than a quartzite one. A Bassian floristic element occurs on the alkaline substrates; however, it is not as strong as that in the island flora of eastern Bass Strait. The flora and vegetation have components that are significant for nature conservation such as remnant Eucalyptus viminalisstands on the sands. The species of conservation significance include rare and threatened species: Pterostylis cucullata, Calochilus herbaceous, Cyrtostylis robusta, Parietaria debilis, Ranunculus amphitrichus and Cotula vulgaris var. australasica.

Key Words: flora, vegetation, fungi, Fleurieu Group, Bass Strait, island, human impact, Conservation Area, conservation, rare and threatened species, weeds, environment history, cattle-grazing impact, International Biodiversity Observation Year 2001-2002.

\section{INTRODUCTION}

Hunter Island, at 7064 ha, is the largest island in the Fleurieu Group off northwest Tasmania. The island is separated from Cape Grim, off the northwestern tip of Tasmania (fig. 1), by the shallow Hunter Passage, which is only $6 \mathrm{~km}$ wide. Formerly known as Barren Island, Hunter Island is situated at $40^{\circ} 34^{\prime} \mathrm{S}$ and $144^{\circ} 45^{\prime} \mathrm{E}$. It is about $24 \mathrm{~km}$ long and between $0.5 \mathrm{~km}$ and $6.5 \mathrm{~km}$ wide.

The island's low altitude, numerous shoals, smaller outlying islands, shallows and strong tidal currents meant it was given a wide berth by the earliest maritime explorers since the island was first observed by Matthew Flinders on his circumnavigation of Tasmania. His fellow officer, Bass, described the island as a "pointed part of the main, which in height and starved vegetation very much resembled Three Hummock Island" (Flinders 1801).

The island became renowned in the 1970s for an important archaeological site at Cave Bay Cave and other sites on the island (Bowdler 1974, 1980, 1984), which established that there had been more or less continuous use of the islands by humans since 23000 years BP. Hope (1978) reconstructed a vegetation history of the island as a background to human occupation. Pollen analysis showed that the island has had similar open shrubby vegetation throughout the Holocene with fires occurring in both occupied and unoccupied phases. Cold steppe vegetation in this area during the Pleistocene was part of a contiguous expanse of open grassland and scattered trees extending from this part of Bass Strait to the Adelaide region. Hope summarised the present vegetation of the island but remarked on the lack of any botanical survey.
Wider systematic vegetation surveys have included Hunter Island and have dealt with particular vegetation types such as heathlands (Kirkpatrick 1977, Kirkpatrick \& Harris 1999), coastal vegetation (Kirkpatrick \& Harris 1995) and wetland vegetation (Kirkpatrick \& Harwood 1981, 1983a, b). While these surveys are aimed at statewide overviews, they have contributed a valuable context for more comprehensive work. No overview of the vegetation ecology of the island has been attempted. Davies (1981) sampled the vegetation of a portion of the coast between Ainslie Beach and Shepherds Bay, sites that were predominantly heathland at that time.

The aims of this study were to describe the current vegetation, make an inventory of vascular plant species and carry out a reconnaissance of the macrofungi. Additionally, we aimed to investigate the principal ecological factors determining vegetation pattern, to assess the conservation significance of the flora and vegetation and to make recommendations on the vegetation management of the island. This study forms part of a wider survey of the flora of the lesser-known coasts and islands of Bass Strait - a project included in the program of the International Biodiversity Observation Year 2001-2002.

\section{METHODS}

This study is based on one visit by both authors to the island between 9 and 19 October 2001, during which $83 \mathrm{~km}$ of foot transects were conducted to cover the major variations in habitat, and a further brief visit by one of us between 3 and 5 June 2002. 


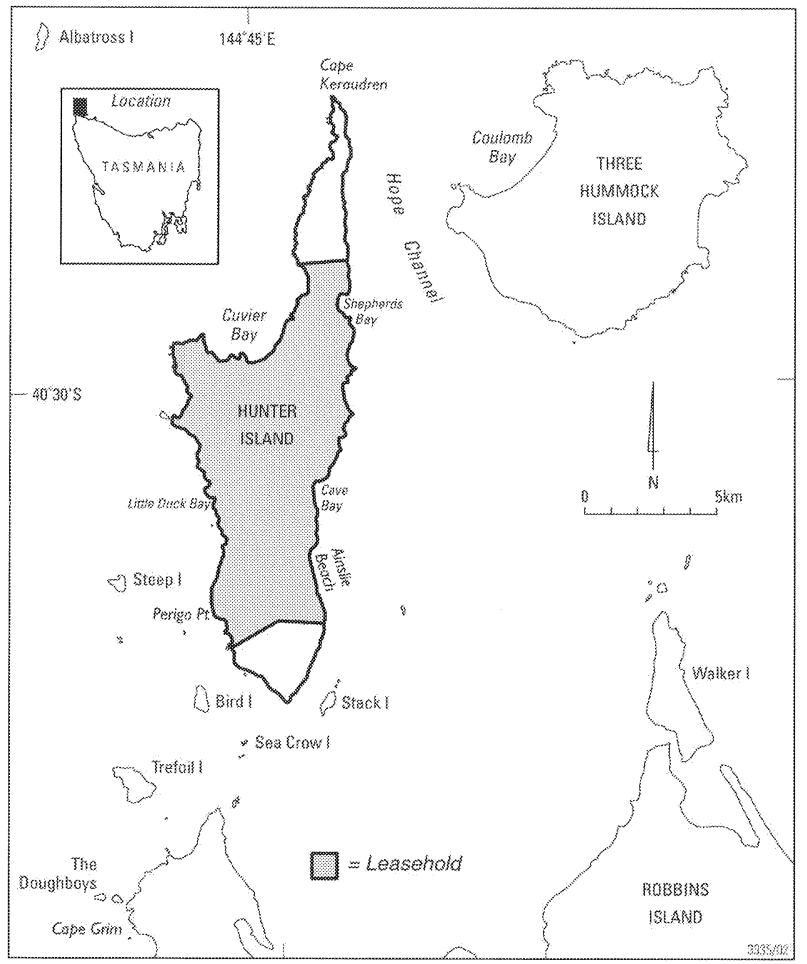

FIG. - 1. Locality of study area.

Information on the geology, soils and climate was synthesised from various published and unpublished sources to provide an environmental context for our vegetation studies. Existing sources were interpreted and supplemented by aerial photograph interpretation of landforms and field observations.

The history of grazing and occupation of the island was assembled through primary and secondary sources. Historical information was supplemented by an examination of earlier black and white aerial photographs dating from 14 January 1968 and 8 January 1980.

Forty-seven plots measuring $10 \times 10 \mathrm{~m}^{2}$ were located to sample variations in habitat. Location of the plots was according to the 'subjective without preconceived bias' approach of Mueller-Dombois \& Ellenberg (1974). Species presence/absence, vegetation structure, soil $\mathrm{pH}$, texture and colour, rock type, fire history and geographical features such as aspect, altitude, topography, drainage and grid reference, were recorded in each plot.

A vascular plant species list was compiled and the voucher specimens of most species were lodged in the Tasmanian Herbarium (HO). A search of the National Herbarium of Victoria (MEL) and the National Herbarium of New South Wales (NSW) was made for specimens from the island. Species occurring on the island were assessed for their nature conservation significance. High levels of rainfall during the October expedition to Hunter Island provided an opportunity to collect several species of macrofungi for identification. Due to the season in which collection was undertaken, the number of specimens was fewer than would be found in the autumn months. The inclusion of a mycological species list in this report is an effort to establish a baseline of information (see recommendations in Scott $e t$ al. 1997). Where possible, all fungi identifications are supported by colour photographs of fresh specimens, comprehensive descriptions and voucher specimens in herbaria.
Photo-communities were mapped from full-colour aerial photographs dated 1 January 2001, which had been enlarged to $1: 26,000$. These photo-communities were checked in the field and, where possible, were allocated to TASVEG statewide mapping communities.

Other observations along the transects were used to supplement the plot information and assist in interpreting the vegetation ecology.

Floristic communities were identified by hand sorting of the plot species lists. Species lists from quadrats collected by Wells (see Kirkpatrick \& Harris 1995) and Davies (1981) and Kirkpatrick \& Harwood (1981) were used to inform the analysis of vegetation types of the island. Records of species by these authors are annotated in our consolidated species list for the island.

Plant nomenclature follows Buchanan (2002) for vascular species except where authorities are given. Macrofungi nomenclature follows Fungi of Australia, Volume 1A (Australian Biological Resources Study 1996). Conservation and reservation status of species and communities was assessed against published lists and the schedules to the Tasmanian Threatened Species Protection Act 1995.

\section{RESULTS}

\section{Physical Description: Geology, Soils and Climate}

Geological reconnaissance of the island (Jennings \& Sutherland 1971) has demonstrated that the island comprises a north-south trending anticline of orthoquartzites and siltstones. The physiography of the island is strongly controlled by the bedrock structure, especially notable along parts of the coast; for example, east of Cape Cuvier where a series of beaches are separated by quartzite ridges and headlands trending conformably with the strike of the anticline.

The island rises to about $60 \mathrm{~m}$ above sea level where a plateau is formed that runs north-south. The highest point is a knoll just over $80 \mathrm{~m}$ above sea level and situated at latitude $40^{\circ} 28^{\prime} 45^{\prime \prime}$, longitude $144^{\circ} 46^{\prime} 40^{\prime \prime}$. Calcareous sand sheets have been blown up on to the western side of the island. Behind Shepherds Bay (see pl. 1) the sand sheet and dune systems bisect the island from west to east. Due west of Ainslie Beach, the quartzite plateau surface is transgressed by the leading edge of a large parabolic dune system.

There are few identifiable surface creeks on the island and surface drainage is otherwise very confused. The drainage is mostly sub-surface where the calcareous sand sheets occur - drainage to the west off the higher quartzite ridge would flow as groundwater towards the west coast where there are numerous coastal bogs, swamps and springs. Some lagoons and swamps occur on the inland margins of the sand sheet where the surface drainage off the quartzite ridge has been impeded. About three streams drain off the quartzite to the east coast and one stream drains to a small beach on the southwest coast. An excellent series of Holocene beach ridges occurs behind Ainslie Beach. Robin \& Parsons (1976) reported such a series of dune ridges at Westernport Bay in Victoria, suggesting they may be an excellent resource for vegetation and soil succession chronosequence work. Like those at Westernport Bay, the Holocene beach ridges on Hunter Island have a vegetation pattern that has been degraded by fire history and stock 


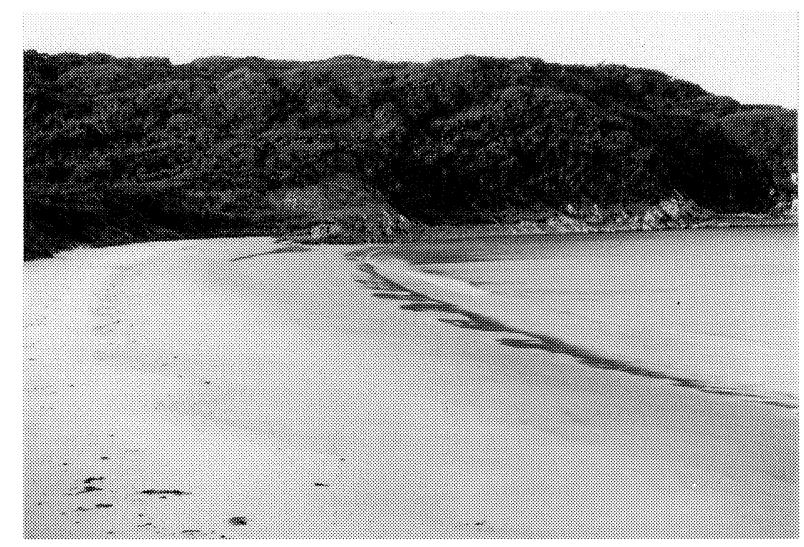

PLATE 1

View to the northern end of Shepherds Bay beach. The ridge consists of an old stable dune over a quartzite base, the quartzite being visible only around the shoreline. Calcium carbonate is leached from the alkaline dunes and precipitated as rimstone pools around the high watermark on the rocky shore. The dune vegetation comprises Leptospermum laevigatum, Banksia marginata, Acacia longifolia subsp. sophorae, Leptospermum glaucescens and Acacia mucronata.

grazing However, the soil development chronosequence may be intact and of potential scientific importance. Lagoons of up to 23 ha occur over the island.

Soils on the quartzite substrates are commonly grey acid (usually $\mathrm{pH} 4.5$ ) sandy loams but in consistently wet areas peats have formed (table 1). Bedrock is exposed in many areas, where only skeletal soil occurs. On the sand sheets the brown loamy sands are highly alkaline $(\mathrm{pH}$ 9) and very friable. An organic horizon occurs on these where a long fire-free period has occurred. The soils under the lagoons are peat.
The island is in the warm humid zone (Gentilli 1972), characterised by a mean annual rainfall of about $900 \mathrm{~mm}$ (based on records between 1961 and 1994). Rain falls throughout the year and the rainfall pattern is probably very similar to nearby Three Hummock Island, which has a monthly maximum of more than $220 \mathrm{~mm}$ in July and a minimum of $10 \mathrm{~mm}$ in February. The temperature is mild throughout the year with daily average temperature ranges of $13^{\circ}-20^{\circ} \mathrm{C}$ in February and $8^{\circ}-12.9^{\circ} \mathrm{C}$ in July (Bureau of Meteorology 1996). The west coast receives the full impact of the westerly ocean swells. The east coast is more sheltered.

\section{Historical Accounts of Vegetation and Habitat}

Matthew Flinders and his crew were the first Europeans known to sight the islands. He assumed that Hunter Island, which he called Barren Island, may have been a part of the mainland of Tasmania. His observation of the island as having “... starved vegetation" (Flinders 1801) and his naming of it Barren Island indicate the vegetation structure may not have been all that much different from today. Howie's comment in 1838 (Howie cited in Buckby 1989) to the effect that the island was "perfectly treeless" and a "kind of scrub overruns its surface" adds extra confidence to this assumption.

On his circumnavigation of Tasmania Kelly met Aborigines occupying the southern part of Hunter Island but it is not clear whether they intermittently visited the island or whether they were a resident band (Kelly cited in Bowdler 1981). Their presence in any case would explain the stature of the vegetation, as fire was a commonly-used instrument for keeping the land open and accessible as well as promoting new growth for macropods.

Hunter and Three Hummock islands were the only areas in Bass Strait to be occupied by humans at the time of European contact. The impact of traditional firing practices was thus continuous on the island for as long as it was on northwest Tasmania.

TABLE 1

Soil properties of the vegetation types of Hunter Island

\begin{tabular}{lllll}
\hline Vegetation community & Soil type & pH & Colour & Drainage \\
\hline Heathlands & sandy loam & 4.5 & 5YR 2.5/1 & good \\
Swamp forests & peat & 8.0 & 7.5 YR 2.5/1 & poor \\
Button grass moorland & peat & 4.5 & 2.5 YR 2.5/1 & poor \\
Exotic grassland & sandy loam & 8.5 & 10 YR 3/2 & excellent \\
Grassland & loam & 6.5 & 2.5 YR 2.5/1 & excellent \\
Eucalyptus viminalis & & & & excellent \\
Woodland & calcareous sand & 8.5 & 2.5 YR 3/2 & poor \\
Wetlands (i) & calcareous sand & $6.5-8.0$ & no record & poor \\
Wetlands (ii) & sandy loam & 4.5 & no record & poor \\
Wetlands (iii) & peat & 4.5 & no record & good \\
Scrub community (i) & sandy loam & 4.5 & 10 YR 3/1 & good \\
Scrub community (ii) & sandy loam & 6.0 & 10 YR 2/1 & good \\
Scrub community (iii) & loam & 9.0 & 10 YR 2/2 & poor \\
Scrub community (iv) & loam & 8.0 & $7.5 Y R ~ 2.5 / 1$ & good \\
Scrub community (v) & sandy loam & 4.5 & $7.5 Y R ~ 2.5 / 1$ & excellent \\
Mutton-bird rookeries & sandy loam & 9.0 & $7.5 Y R ~ 3 / 2$ & \\
\hline
\end{tabular}


Under the guidance of G. A. Robinson, a settlement was made on the east coast, probably near Ainslie Beach (Bowdler 1980) for use as a concentration camp for Aborigines in 1832. After a short time the camp moved to the west coast, presumably because of the more abundant marine food resources (O'Connor 1982) and also, we suggest, because of the suitability of the grassy Eucalyptus viminalis forests for camping.

In October 1837 Ronald Gunn visited the island and collected some plants. In the following year, the island was mentioned in a letter from Howie, resident on King Island, to the then Surveyor-General. He stated "Hunter Island well deserves its former name of Barren, for it is perfectly treeless; a green kind of scrub overruns its surface, which at its highest point is three hundred feet above the level of the sea". Howie was applying for occupation of an area at Cuvier Bay in 1838. This was the same year that HMS Beagle was carrying out hydrographic survey work in the vicinity. Lieutenant Stokes in fact, walked on the plateau to get bearings on coastal features. One of his assistants referred to accompanying Stokes "over dreadful brushwood summits" (Hordern 1989).

The use of the island for grazing purposes began in the 1850 s when Dr James Grant was granted a lease in 1853. In 1860 a report on the island suggested that "Hunters Island well suited for cattle, and also well watered; these islands will carry a large number of cattle - from 5001000 head each. Sheep will not do from the presence of the cotton plant". The occupation of the island by lessees for cattle grazing has been more or less continuous since (Buckby 1989).

This grazing period, which has persisted to the present day, has had a large impact through clearing of the vegetation on the calcareous sands, and the sowing of exotic pasture species. Implicit in a letter written by the lessee of the island in 1870, is a landscape with dense native tussock grasses and no exotic pasture: "Up to the present time we have made a very heavy loss, the grasses being too rank for fattening. The only chance of making the place pay would be by spending a considerable amount on improvements, English grasses etc." (cited in Buckby 1989: 47). Introduced garden and ornamental plants have been established around the house site but these have not spread (pl. 2).

Most of the island is presently held under a grazing lease comprising 6980 ha (fig. 1). While there are cattle confined to paddocks, there is also an undetermined number that are feral and these are presently to be encountered throughout the island (pl. 3). The observed impacts of the feral cattle include pugging of soaks and wetland margins, physical damage to beach dunes and physical damage to scrub understorey in the vicinity of camps.

\section{The Vegetation}

\section{Heathlands}

Heathlands are the most extensive vegetation formation on the island, covering 2672 ha or $38 \%$ of the island. The heaths are maintained by fire on shallow well-drained sandy loams over quartzite basement. Heath also occurs on some localised accumulations of sand. Species richness is fairly uniform throughout the heathlands with mean vascular species diversity in $10 \times 10 \mathrm{~m}^{2}$ plots of 18 species and the maximum recorded for a plot being 30 species.

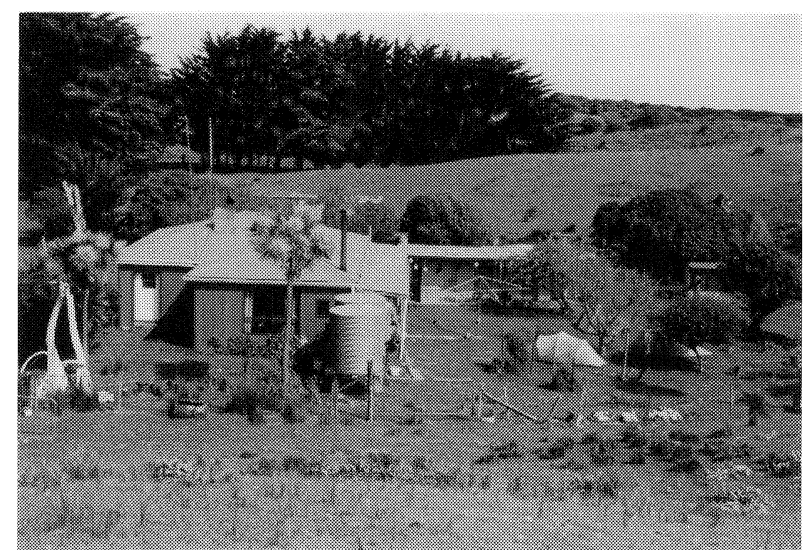

\section{PLATE 2}

The main homestead on Hunter Island is sheltered by Cupressus macrocarpa. The house is surrounded by many ornamental and garden plants including Cordyline australis, Agapanthus, Prunus and Hydrangea.

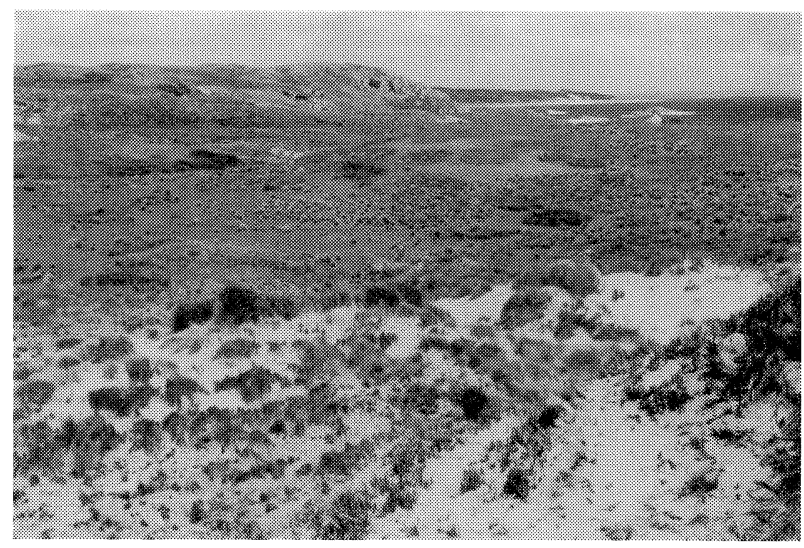

PLATE 3

Looking south on the west coast towards Perigo Point. The exotic pasture is interrupted by Poa tussocks and colonies of Isolepis nodosa. In the right foreground cattle have heavily grazed a sward of Lepidosperma gladiatum. A tongue of sand in the near distance has been colonised and stabilised by Ammophila arenaria.

Three different floristic communities were identified, each of which fits three different heath types (defined in Kirkpatrick \& Harris 1999). The most extensive of these is the soft-fruited dry heath represented by various facies of floristic community 26. These heaths occur widely on the plateau surface. In some sites, Eucalyptus nitida forms coppices and occurs in an open shrub layer up to $2.5 \mathrm{~m}$ high, co-dominant with Leptospermum glaucescens, Acacia mucronata and Banksia marginata. In some sites the emergent shrubs may be only $50 \mathrm{~cm}$ over a heath layer of $20-30 \mathrm{~cm}$. In the latter sites the last fire was two to three years ago whereas the site example with the $2.5 \mathrm{~m}$ shrub layer was previously burnt 24 years ago.

Commonly occurring species in the island quadrats for this heath type include Leptospermum glaucescens, Banksia marginata, Epacris impressa, Aotus ericoides, Dillwynia glaberrima, Allocasuarina monilifera and Lepidosperma concavum. 

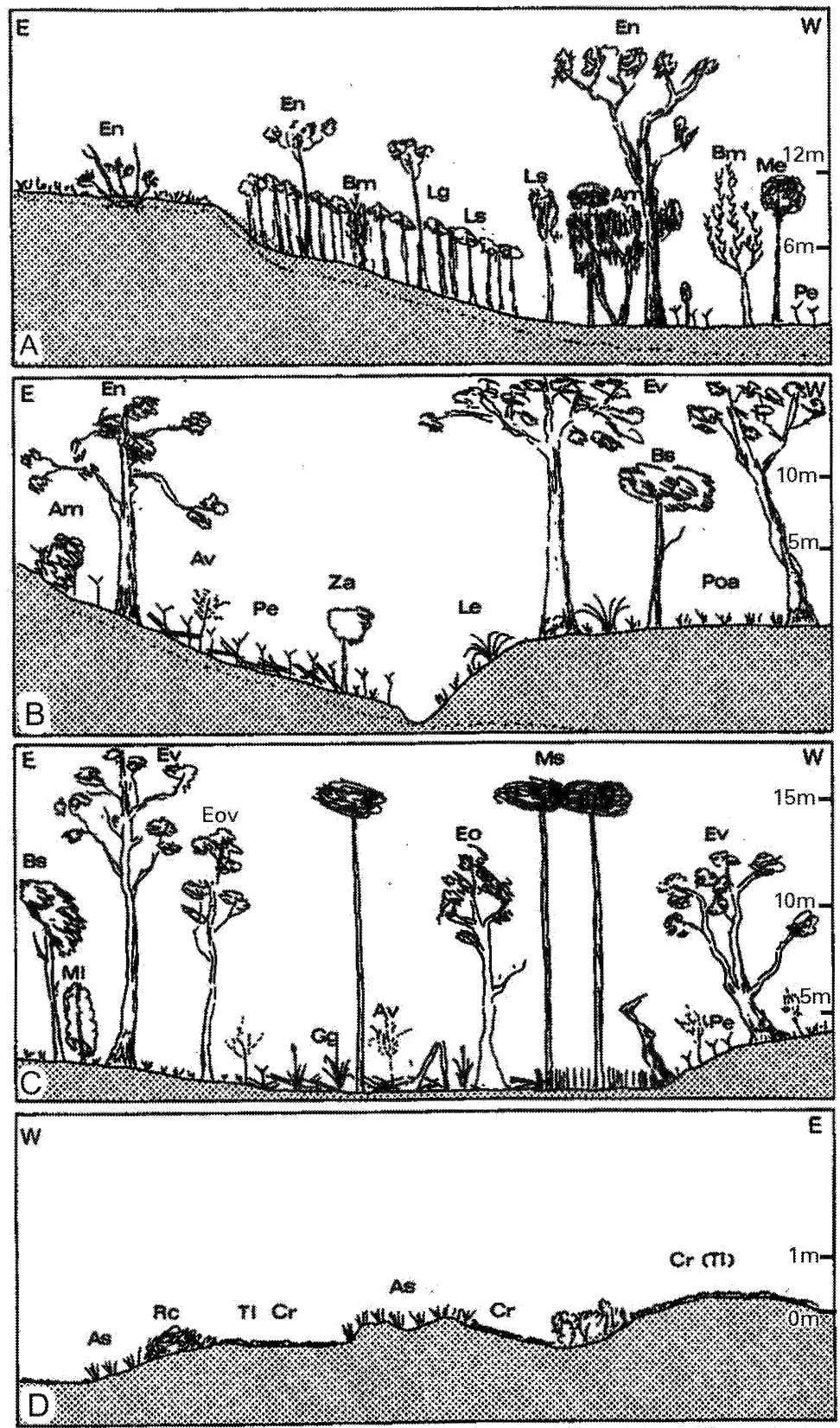

FIG. 2. - Profile diagrams showing the nature of some vegetation boundaries.

(A) The western margin of the plateau surface is marked by a typically abrupt transition from heathland and shrubland to scrub and forest. The depth of soil increases to the west and the fire frequency decreases from the plateau heathland to the forest. The form of Eucalyptus nitida changes across the profile - coppiced mallee-form specimens on the plateaus to tall single-stemmed trees in the forest.

(B) The dramatic boundary between lower pediment slopes of the plateau on the left and the toe of the old alkaline sand sheet on the right is marked by a narrow creek-line. To the east is shrubby Eucalyptus nitida forest on shallow acid soils and west of the creek-line is well-developed grassy Eucalyptus viminalis (Bursaria spinosa) forest on the deep alkaline soils.

(C) A Melaleuca squarrosa swamp occupies a low flat on the alkaline sand sheet. The higher ground is occupied by Eucalyptus viminalis (Eucalyptus ovata) forest.

(D) Cape Keraudren is fully exposed to westerly weather and has large salt loads dumped on it. This profile demonstrates the low-pruned shrubberies, succulent mats and salt-hardy grasses that make up the vegetation mosaic on the cape.

Plant symbols: $A m=$ Acacia mucronata, $A s=$ Austrostipa stipoides, $A v$ = Allocasuarina verticillata, $B m=$ Banksia marginata, $B s=$ Bursaria spinosa, $C r=$ Carpobrotus rossii, $E n=$ Eucalyptus nitida, Eo = Eucalyptus obliqua, Eov = Eucalyptus ovata, $E v=$ Eucalyptus viminalis, $G g=$ Gahnia grandis, $L e=$ Lepidosperma elatius, $L g=$ Leptospermum glaucescens, $L s=$ Leptospermum scoparium, $M e=$ Melaleuca ericifolia, $M i=$ Myoporum insulare, $M s=$ Melaleuca squarrosa, $P e=$ Pteridium esculentum, $P o a=$ Poa $s p p, R c=$ Rhagodia candolleana, $T i=$ Tetragonia implexicoma, $Z a=$ Zieria arborescens. 
Floristic community 67 , scented paperbark wet heath, is almost as abundant as the previously described community. This vegetation community is found on poorly-drained acid peat $(\mathrm{pH} 4.5)$ or acid sandy loams, of variable depth. The sites sampled were sedgy heaths in one case with Leptospermum glaucescens emergent at $60 \mathrm{~cm}$. Common species recorded in this heath type included Leucopogon australis, Melaleuca squamea, Pultenaea dentata, Aotus ericoides, Epacris lanuginosa, Epacris impressa, Drosera peltata, Boronia citriodora and B. parvifolia. There have been fires in this heath type in the last two to three years. At two sites there is evidence of fire having occurred about 27 years and 15 years respectively prior to the most recent burn. On the site with the 27-year fire interval, the vegetation had grown into a $3 \mathrm{~m}$ high scrub with a high component of Banksia marginata and Leptospermum scoparium.

Swamp paperbark dry heath was sampled by recording species assemblages approximating floristic community 3 . This type occurs on well-drained acidic soils on the central eastern plateau of the island. The soil profile has a peaty or loamy A-horizon. This community is more likely to be floristically closer to a scrub community than to some of the other heath communities. That is, in the absence of fire, this type would revert more rapidly to scrub than some other heath communities.

\section{Swamp forests}

Swamp forests make up only 34 ha or $0.5 \%$ of the island. They occur on deep, peaty soils on the leading edges of the alkaline sand sheets. These Pleistocene sand sheets, blown onshore from the west, have ponded the drainage coming off the topographically higher quartzite plateau and ridges. Depending on the topography of the bedrock basement, some groundwater drainage may be directed from the sand sheets to the swamps.

The swamp forests are dominated by Melaleuca squarrosa up to $20 \mathrm{~m}$ high; they form dense apparently even-age stands over an understorey dominated by Carex appressa and Gahnia grandis. In one locality a tall blackwood (Acacia melanoxylon) was observed; in another Eucalyptus obliqua up to $10 \mathrm{~m}$ high was noted. Both these trees are rare on the island and are likely to be relicts of more extensive stands. Their occurrence at trace levels prompts the question of whether fire frequency became inimical to their survival. In the swamp forest where the canopy has been broken (fig. 2C), there is extensive tree-fall and the dense scrubby layer comprises Gahnia grandis, Acacia verticillata subsp. verticillata, Pimelea sp. and Urtica incisa. Wind may be the cause of the broken canopy in the swamp forest. While the canopy of such closed forests remains intact, wind flow is smooth but as soon as the canopy surface is opened a small amount wind turbulence increases and breaks down the forest.

The swamp forest observed by us falls into the depauperate tea-tree scrub forest type (Pannell 1992). This community occupies better-drained sites than those of other swamp forest types. In some areas sampled by Kirkpatrick \& Harwood (1983a, b) the forests tend to be dominated by Melaleuca ericifolia, with Carex appressa and Gahnia grandis present as understorey species. These would fit the depauperate tea-tree/paperbark scrub forest type. Examination of aerial photographs in a sequence from 1968, 1980 and 2001 indicates that small patches of depauperate tea-tree scrub forest have survived intact through 30 years of very high fire frequency. In the absence of fire it is conceivable that the diminutive Melaleuca ericifolial $M$. squarrosa scrubs fringing many of the smaller lagoons on the quartzite substrates would develop into tall scrub and low closed forest.

\section{Button grass moorland}

The patch of button grass (Gymnoschoenus sphaerocephalus) moorland on Hunter Island falls into the Eastern Moor (Lowland form) type (Jarman et al. 1988). Its floristic composition best fits the category Common West Eastern Heath (ElCa) in the classification by Jarman et al. (1988). The patch occupies a poorly-drained saddle between rises on the highest part of the quartzite plateau and covers about four hectares on peat more than $30 \mathrm{~cm}$ in depth. The saddle gently slopes to the west and is exposed to the predominant weather direction. The button grass hummocks are welldeveloped and cover $40 \%$ of the site with a sedgy heath occupying the remainder. The species we recorded included the graminoids Hypolaena fastigiata, Thelionema caespitosa and Empodisma minus, shrubs Sprengelia incarnata, Epacris impressa, Dillwynia glaberrima, Hibbertia riparia, Boronia parviflora, Melaleuca squamea, Epacris lanuginosa and Bauera rubioides, and ferns Lindsaea linearis and Selaginella uliginosa. Emergent shrubs of Banksia marginata and Leptospermum scoparium up to $1.6 \mathrm{~m}$ high occupy about $5 \%$ of the site. The site appears to have been frequently burnt with the previous fire being about six years ago and a fire about 18 years before that. This is the only known button grass site on any of the islands in western Bass Strait (pl. 4).

\section{Exotic grasslands}

Exotic grasslands cover 835 ha or $12 \%$ of the island and are confined entirely to the deep, alkaline calcareous sands on its western side. Earliest grazing would have relied on the persistence of the native grasses, mainly Poa poiformis and various inter-tussock herbs. Exotic grasses and clovers that have persisted and dominate in the pasture are Holcus lanatus, Triticum, Hordeum, Bromus and Trifolium spp. Introduced pasture weeds include Bellis perennis, Arctotheca calendula, Plantago spp., Cerastium and Cirsium vulgare. The native herbs and grasses that have persisted to different degrees within the pasture area include Ranunculus sp., Poa poiformis, Ajuga australis, Isolepis nodosa, Gnaphalium indutum and Dichondra repens.

The exotic grasslands were more extensive in 1968; since then there has been invasion of sand sheets by shrubs.

\section{Grasslands}

The native grasslands are mapped as a strip of vegetation on the west coast of Cape Cuvier, although distinct fragments of this native grassland occur on other parts of the east and west coasts. The grassland comprises Austrostipa stipoides tussock grassland on the near coastal margin, its width being proportional to the amount of exposure to salt-laden onshore winds (pl.5). Inland from the Austrostipa tussock grassland there is Poa poiformis tussock grassland. The co-occurring species include Disphyma crassifolium, Sarcocornia quinqueflora, Distichlis distichophylla and Lobelia anceps. More bare ground is exposed in the Austrostipa zone than in the Poa poiformis zone where the number of inter-tussock herbs increases. On the eastern shore there are patches and strips of Ammophila arenaria and Spinifex sericeus in quantities too small to be mapped separately. On the central west coast, mapped as exotic grassland, Poa poiformis tussocks form the dominant stratum over most exotic species. 


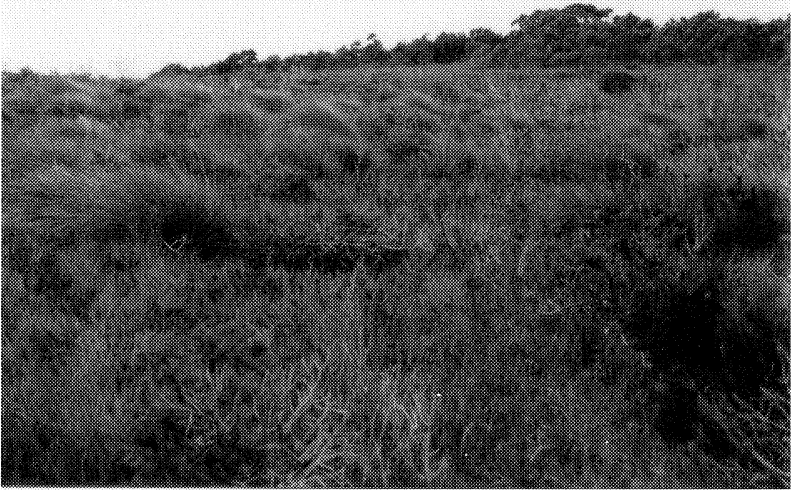

PLATE 4

Button grass (Gymnoschoenus sphaerocephalus) moorland near the central-north of the island.

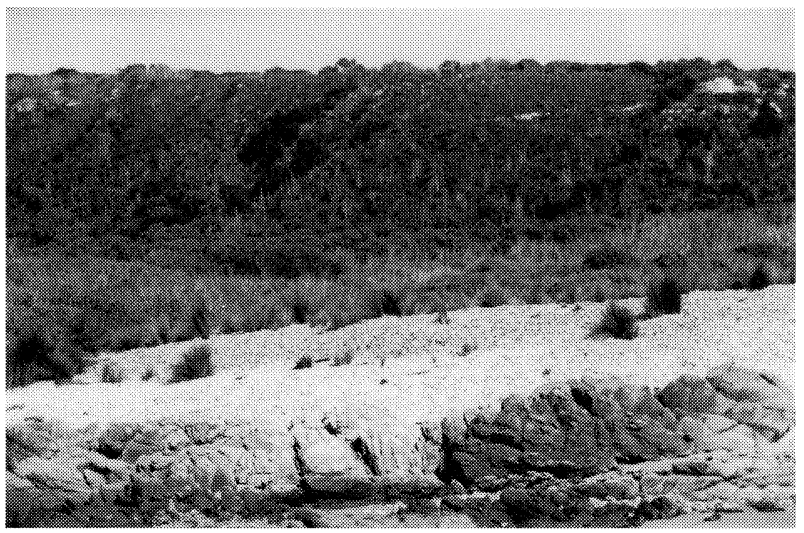

PLATE 5

The escarpment slope behind Ainslie Beach. A foredune composed of shell remains is being colonised by Austrostipa stipoides. The dark lineations on the escarpment are scrub remnants of repeated fires; they are aligned according to the direction of wind-driven fires.

\section{Eucalyptus viminalis woodland}

This vegetation type occupies only 389 ha or $6 \%$ of the island and is a relict of a more widespread former distribution coinciding with the calcareous sand sheets that are welldrained, alkaline and fertile. This vegetation type has suffered the greatest reduction in extent since the occupation of the island by Europeans.

The landward fringes of the sand sheets have some remnant stands of E. viminalis woodland (or rarely, forest). A good example was located northwest of the airstrip and is bisected by the Cape Cuvier track (pl. 6). Here the E. viminalis low forest canopy is $8 \mathrm{~m}$ high and has a $35 \%$ cover (see Mueller-Dombois and Ellenberg 1974 for descriptive conventions). Subdominants in the sparse shrub layer at $2 \mathrm{~m}$ are Acacia longifolia subsp. sophorae, Leucopogon australis, Banksia marginata, Acacia verticillata subsp. verticillata and Pimelea linifolia. A patchy bracken layer at $80 \mathrm{~cm}$ high occupies $20 \%$ cover. About $70 \%$ of the ground layer is grassy comprising Poa poiformis. Inter-tussock herbs

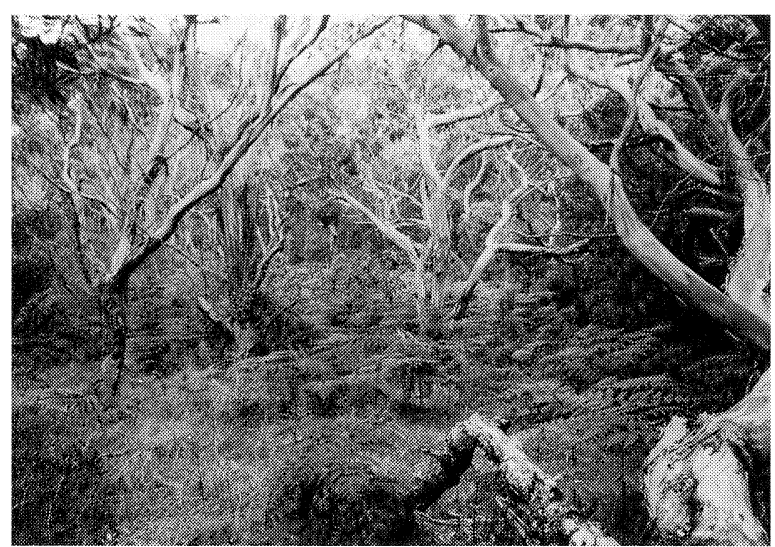

\section{PLATE 6}

This grassy Eucalyptus viminalis forest has developed on the alkaline sand sheet northwest of the main airstrip. The forest has developed over 30 years from a sparse open grassy Eucalyptus viminalis shrubland.

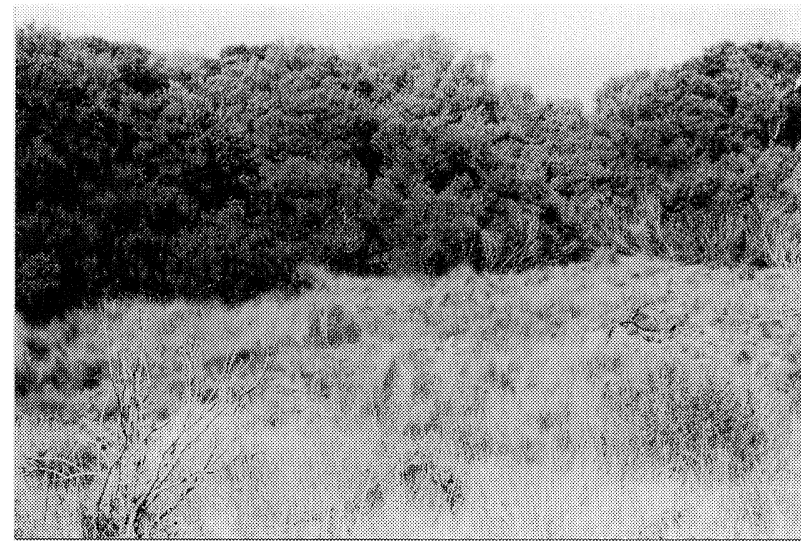

\section{PLATE 7}

A grassy opening in the scrub on an extensive tongue of sands between the homestead and Weber Point. Thirty years previously, this area was Poa tussock grassland with rare scattered shrubs. The darker shrub on the left is Acacia longifolia subsp. sophorae, which is rapidly encroaching on the open area.

include Hydrocotyle sp, Swainsona lessertiifolia, Dichondra repens, Ajuga australis, Oxalis perennans, Galium sp., Geranium sp. and Hibbertia sericea.

Nodal counts on the Banksia marginata indicate a fire approximately 16 years previously (1985). South of the homestead adjacent to the southern track many E. viminalis trees still persist - these are up to $60 \mathrm{~cm}$ in diameter across the bole. These scattered trees are survivors of frequently burned open grassy woodland. Clearly the fire regime has enabled the persistence of these relicts. Since the changes in management of the island to a less interventionist technique, the process of vegetation thickening has proceeded with abundant regrowth of scrub comprising Leptospermum laevigatum, Banksia marginata and Acacia longifolia subsp. sophorae. Some seedlings of $E$. viminalis are now visible at some sites. Acacia longifolia subsp. sophorae is a vigorous coloniser that is advancing rapidly from scrub edges into open patches (pl. 7). 


\section{Wetlands}

The wetlands cover 43 ha or $0.6 \%$ of Hunter Island and fall into three categories (fig. 3):

(i) Wetlands on the calcareous sand sheet. These are closer to the west coast of the island, are topographically lower than the other two categories and have more alkaline substrates. They have the highest complement of plant species, including $61 \%$ of its combined wetland flora not being shared by the other two groups of wetlands. Some of the species recorded only in the sample as wetland species in this group on Hunter Island are Juncus articulatus, J. caespiticius, J. holoschoenus, J. bufonius, J. pallidus, Isolepis cernua, Triglochin striatum, Selliera radicans, Carex fascicularis, Hydrocotyle pterocarpa, Crassula helmsii and Cardamine heterophylla.

(ii) The small lagoons perched on the quartzite plateau surface have acid substrates, sandy inorganic floors and are topographically higher than the other two categories of wetlands on the island. Of those we observed, only one appearing typical was sampled. The sampled lagoon had only one plant species (Drosera pygmaea) not found in the other two categories of wetlands.

(iii) The lagoons occupying a zone between the other two wetland types are deflation hollows in acid sands with a peaty floor. This group had six species that were not recorded in the other two wetland types. Some of the species recorded only as wetland species in this group include Selaginella uliginosa, Juncus procerus, Callitriche stagnalis, Myriophyllum amphibium, Isolepis fluitans and Baumea arthrophylla.

The wetlands are clearly divided into the three groups above on the basis of geomorphology and have distinctive floristic attributes (species richness was compared between the groups by Chi Square and was significant: $\mathrm{P}<0.2$ ). The wetlands on the alkaline sands and the acid sands both have the same number of plant species, both more than were sampled on the quartzite surface. The proportion of species unique to each group shows a marked decline further from the wetlands on calcareous dunes, which have three times more unshared species than the wetlands on the acid sands which, in turn, have a third more than the lagoons on the quartzite surface.

The lagoons on the quartzite plateau are more floristically related to the precipitation dominant wetlands of southwest Tasmania (Buckney \& Tyler 1973) whereas the other two groups are more abundant throughout the northwest and northeast of Tasmania including the larger islands of Bass Strait.

The wetlands have had varying degrees of impacts, mainly from cattle and fire incursion into the edges. Cattle have a big impact on the remaining wetlands on the calcareous sand sheets particularly where grasslands surround them.

\section{Scrub communities}

Scrub communities are extensive on the island and cover 2649 ha or $37 \%$ of the island.

Any lapse in the traditional fire regime will result in the development of scrub from heathland. It is apparent from historical sources that the proportions of scrub and heath have oscillated. When Robinson walked about the island in the 1830s his commentary implied that the vegetation was very open. This was probably due to the traditional burning practices of the Aboriginal people who used the island. When Dr Grant took up his lease in the 1850s the island was densely scrubby due to the cessation of fire when the

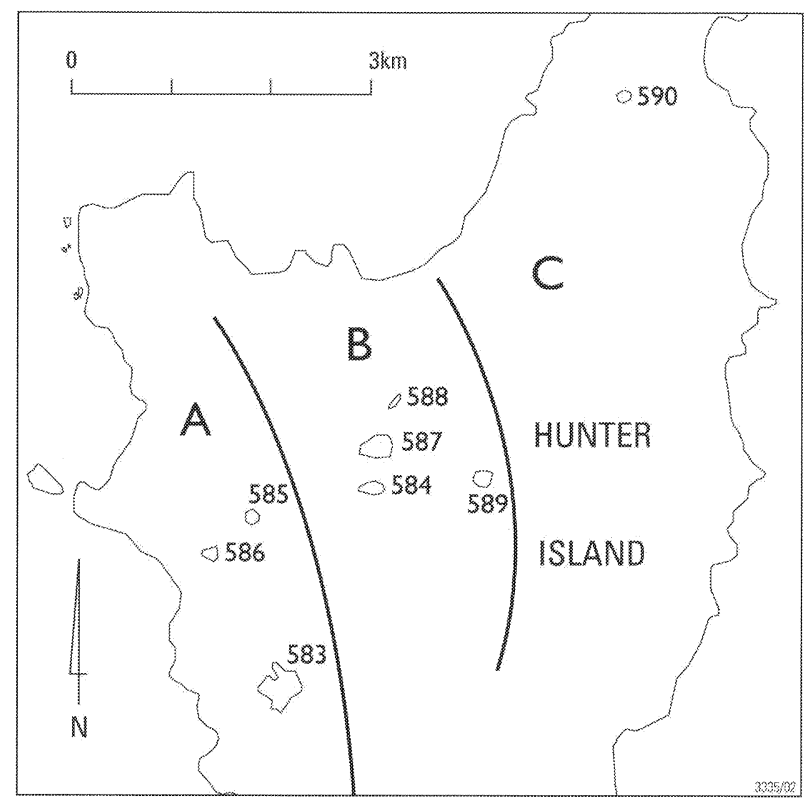

FIG. 3 - Distribution and typology of wetlands sampled by Harwood on Hunter Island. A= Zone of wetlands on calcareous alkaline sand sheet. $B=$ Zone of wetlands on deflation hollows in acid sands. $C=$ Lagoons on quartzite plateau with no organic floor (lowest species diversity). Locations of wetlands are from Kirkpatrick of Harwood (1981).

Aborigines were moved off. Photographs of the island in the 1970s indicate that the proportion of scrub to heath was much lower than it is now.

The scrubs can be conveniently divided into five types: myrtaceous scrubs on acid substrates; myrtaceousmimosaceous scrubs on calcareous sands; lagoon fringing dense scrubs; Eucalyptus ovata riparian scrub; and scrub on Holocene sand dunes on the east coast.

(i) The myrtaceous scrubs on acid sands (pl. 8) include Eucalyptus nitida-dominated scrub on the areas that are more fire-protected, such as along the eastern escarpment of the plateau. These scrubs are co-dominated by Banksia marginata and Leptospermum scoparium, with a diverse mix of species in the understorey. The rocky nature of the ground surface provides a diversity of niches for species to occur, some fire-protected (pls 5, 9) some shady and some very dry. The soils are very skeletal along the escarpment face and at its most convex portion there were individual Eucalyptus nitida and Banksia marginata that appeared to be dying due to drought.

(ii) The myrtaceous-mimosaceous scrubs on calcareous sands appear to be consistently dominated by Leptospermum laevigatum, Acacia mucronata and Acacia longifolia subsp. sophorae. Leucopogon australis is also common. The understorey comprises a few tussocks of Poa poiformis and scattered Isolepis nodosa. The soil is typically a deep, welldrained, alkaline, humic loam. Many of these areas that are now dense scrub were open grassy shrubland or woodland 30 years ago.

Open patches usually resulting from wind throw, burning or other disturbances, have an interesting diversity of small herbs and sedges. These include the endangered orchid Pterostylis cucullata, the uncommon herb, Minuartia mediterranea, and Gnaphalium indutum, Carex breviculmis, Ajuga australis, Dichondra repens and Luzula campestris.

(iii) The lagoon-fringing scrubs comprise dense thickets 


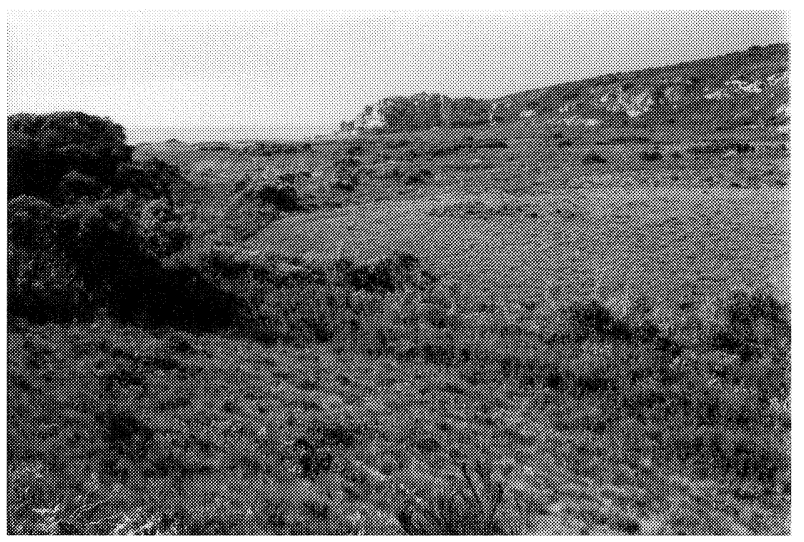

PLATE 8

From the track to the homestead, looking southwest across to Cave Bay. Eucalyptus ovata scrub lines the creek. The plateau escarpment is in the distant right.

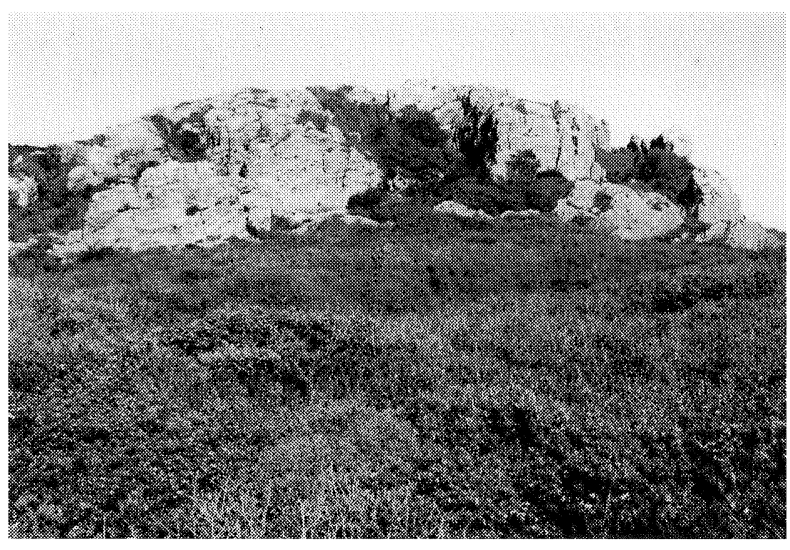

PLATE 9

The eastern coastal swamp south of Cave Bay, showing the heathy coastal margin shelf and the small pockets of myrtaceous scrub, which have escaped the higher fire frequencies of the coastal shelf.

of Melaleuca ericifolia and $M$. squarrosa. Where lagoons are on uncleared land, these scrubs developed markedly in the period between 1968 and 2001. Melaleuca scrubs over time encroach on the actual lagoon forming mature swamp forest.

(iv) Eucalyptus ovata is usually less than $8 \mathrm{~m}$ high and dominates the dense scrub along the few creek-lines draining the plateau surface (pl. 8). At one apparently typical site $E$. ovata 4-5 $\mathrm{m}$ high was emergent above a dense layer at 2$3 \mathrm{~m}$ of Pomaderris apetala subsp. apetala, Acacia verticillata subsp. verticillata, Lepidosperma elatius, Gahnia grandis, Leptospermum scoparium, Melaleuca squarrosa and Pimelea drupacea. Other species in the understorey included Urtica incisa, Viola hederacea, Gonocarpus teucrioides, Acaena novaezelandiae, Muehlenbeckia appressa and Hydrocotyle sp.

(v) The scrub on the acid Holocene dunes on the east coast is floristically similar to the myrtaceous scrubs on acid substrates but with the addition of some littoral and near coastal elements.

\section{Mutton-bird rookery vegetation}

The principal mutton-bird rookeries occur at both the southern and northern extremities of the island; in each case the vegetation is composed of a patchy mosaic of succulent herbfield dominated by Carpobrotus rossii and a succulent shrubland dominated by Rhagodia candolleana and Tetragonia implexicoma (fig. 2D). Woody shrubs in the rookery areas include Olearia axillaris and Myoporum insulare. Most of the other species are disturbance-requirers including Sonchus oleraceus, Cerastium glomeratum, Urtica incisa and Cirsium vulgare. The Carpobrotus rossii succulent herbfield at Cape Keraudren is probably the largest in the state and is approached in size only by those patches found on the northwest coast of Prime Seal Island in the Furneaux Group (Harris et al. 2001).

Rock (lichen-fields)

Most of the exposed rock occurs around the coast and is especially extensive on the west coast where a wide rocky zone is maintained free of vegetation by the persistently heavy seas. Bluffs and cliffs mark the edge of the plateau escarpment down the eastern side of the island and some rocky bluffs indicate a fossil shoreline inland along parts of the west coast. Close inspection of these rocky areas, except for wave-washed rocks, revealed lichen-fields, the composition of which remains to be explored.

\section{The Flora}

As a result of this, and previous studies, 293 vascular plant taxa have been recorded on the island, representing 199 genera in 76 families (see appendix 1). The best-represented families are Asteraceae ( $n=27$ taxa), Poaceae ( $n=26$ taxa) and Cyperaceae $(\mathrm{n}=21$ taxa). Four Tasmanian endemic species were recorded. Ammobium calyceroides is an endemic herb confined to the littoral salt spray zone predominantly around Tasmania's west coast and the larger islands of Bass Strait. Eucalyptus nitida has closer affinity in form to those on Flinders Island than to other western Tasmanian populations (Rankin 1998). Phyllota diffusa is a widespread but uncommon shrub of coastal heathland. Leptospermum glaucescens is a common shrub in Tasmanian coastal heathlands.

The species listed on the schedules of the Tasmanian Threatened Species Protection Act 1995 are Parietaria debilis, Cotula vulgaris var. australasica, Calochilus herbaceous, Cyrtostylis robusta, Ranunculus amphitrichus and Pterostylis cucullata. The first five are listed as rare on Schedule 5; and Pterostylis cucullata is listed as endangered on Schedule 3 of the Act. There are some other species of bio-geographical interest and some forms of taxa, which represent extremes in the range of variation. Pultenaea dentata is a distinctive form characterised by leaf shape, colour and the presence of a few hairs. It bears a superficial resemblance to Almaleea subumbellata.

Olearia glutinosa has its stronghold on King Island with occurrences recorded for Three Hummock Island (Harris \& Balmer 1997) and now Hunter Island. There is a specimen in the Tasmanian Herbarium from a collection at the beginning of the track across Robbins Island. Other specimens are occasionally observed in the far northwest of the Tasmanian mainland but no populations have become established. It has been suggested (A. Buchanan, pers. comm.) that seed is blown from King Island and that resulting propagules cannot gain a foothold.

Atriplex billardierei was collected from one site on a sandy beach south of Wallaby Point on the west coast. This species is widespread in Tasmania but is very uncommon. 


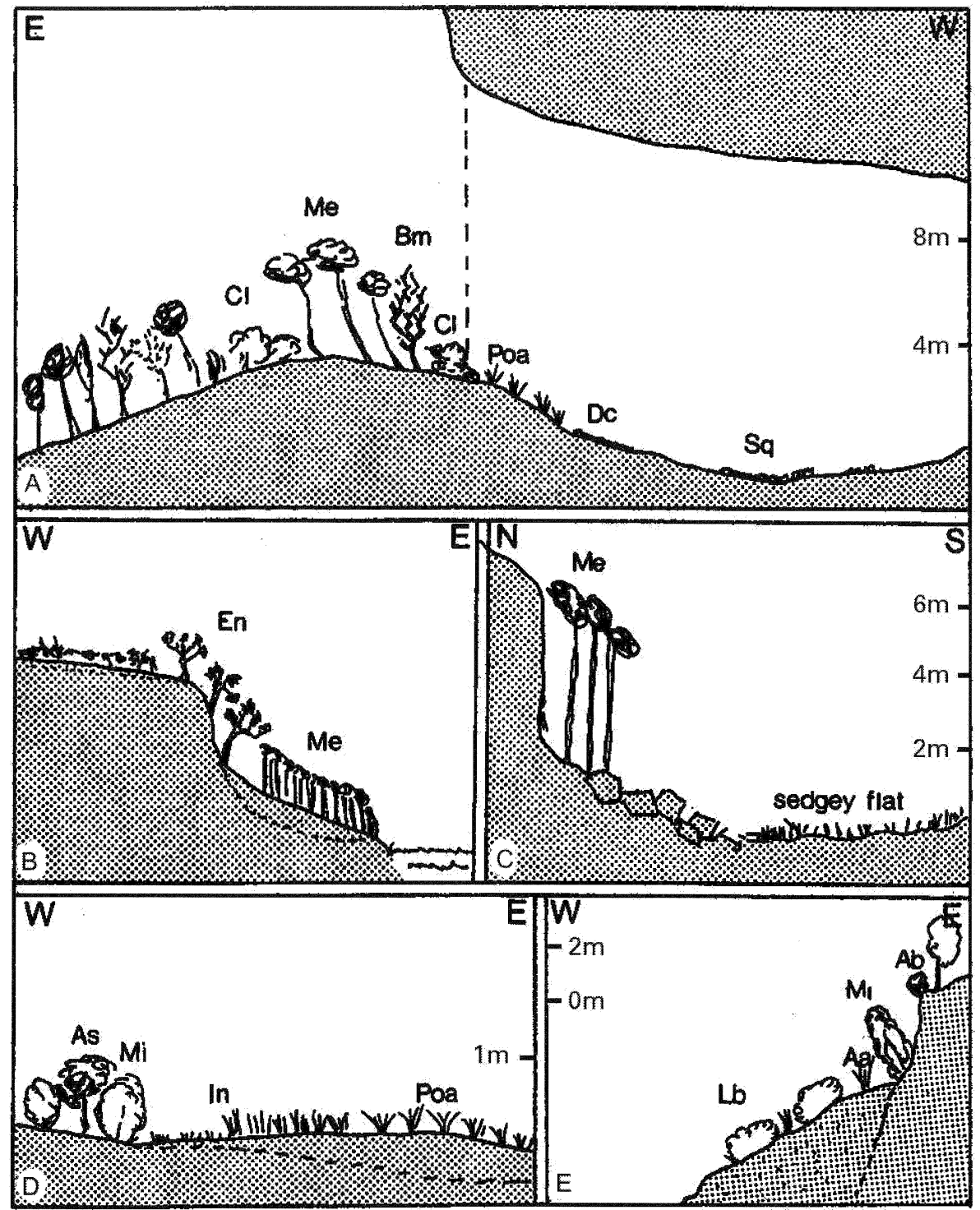

FIG. 4 - Five diagrammatic vegetation profiles from Hunter Island.

(A) The mouth of Cave Bay Cave. The dashed line is the drip line to the west of which the only substantial moisture available is from rain and sea mist blown into the cave. Mats of succulent plants occur in the cave mouth where salt-laden moisture collects. (B) A stylised section of the east coast north of Cave Bay Cave showing the relative positions of the myrtaceous scrub on the deeper soils of the coastal shelf margin, the Eucalyptus nitida trees on the rocky escarpment and the heathland on the plateau surface where fire frequency has been highest.

(C) An inland bluff, probably representing an older sea cliff during a still stand, now has a pediment of angular scree. This profile shows Melaleuca on the southern side of a bluff where conditions are moist enough to support the lithophytic fern Asplenium obtusatum.

(D) A boundary between scrub and seabird rookery at the northern end of Hunter Island. Poa poiformis grassland that characterises the rookery is on deeper sandy soil.

(E) A steep ramp of sand blown up against a cliff on the western shore is unstable and dominated by two species typical of unstable coastal sands, Leucophyta brownii and Ammophila arenaria. The cliff species are mainly Alyxia buxifolia and Myoporum insulare.

Plant symbols: $A a=$ Ammophila arenaria, $A b=$ Alyxia buxifolia, $A s=$ Acacia longifolia subsp. sophorae, $B m=$ Banksia marginata, $C l=$ Correa lawrenceana, $D c=$ Disphyma crassifolium, $E n=$ Eucalyptus nitida, $I n=$ Isolepis nodosa, $L b=$ Leucophyta brownii, $M e=$ Melaleuca ericifolia, $M i=$ Myoporum insulare, $P o a=$ Poa poiformis, $S q=$ Sarcocornia quinqueflora. 
Minuartia mediterranea is a tiny introduced herb that has been rarely collected in Tasmania. It has probably been overlooked by many botanical collectors and has been collected previously only on calcareous sands on King Island and Three Hummock Island.

Neither Eucalyptus obliqua nor Acacia melanoxylon have been recorded from the island before. These trees are rare on the island. Eucalyptus obliqua occurs commonly in northwest Tasmania and on King Island (Williams \& Potts 1996); Acacia melanoxylon is similarly abundant on the adjacent mainland and on King Island (Kirkpatrick \& Backhouse 1997). Their occurrence in trace proportions may be due to a fire frequency that has disadvantaged them. Acacia melanoxylon is known to require between ten and 20 years without intense fire prior to producing seed in the northwest (Sue Jennings, pers. comm.). Eucalyptus obliqua is a wet forest species not known to form coppices or large lignotubers, and is therefore more adversely impacted by high fire frequencies than Eucalyptus nitida.

Gymnoschoenus sphaerocephalus is a record from the island of biogeographical interest. The species has not been recorded from King Island or other islands in the Fleurieu Group; the Hunter Island occurrence represents a northwestern outlier of the species.

The orchid Pterostylis cucullata was flowering at the time of our fieldwork. This endangered nationally and statelisted species was represented by a localised population of $>100$ specimens on the south-facing slope of a calcareous dune northwest of the homestead, in the vicinity where it has previously been reported. Cattle do not have access to the dune in keeping with an earlier recommendation that the Pterostylis area be fenced off. No damage by garden snails (Helix aspersa) was apparent, as feared by an earlier observer (DPIWE file 50-28-04). A new site for the orchid was found on a dune in scrub at the southern part of the island, at a site burnt about two or three years prior to our survey.

\section{Introduced Species}

Sixty-five taxa, comprising $22 \%$ of the total Hunter Island flora, are introduced in Tasmania. The most ubiquitous on the calcareous sand sheets outside pasture areas are Aira caryophyllea, Cerastium sp. and Hypochoeris radicata. The acid soils in heath and scrubs are remarkably weed-free in spite of free-roaming cattle. Lagoons and remnant swamp forests appear also to be weed-free. Weed problems are evident in the coastal swamps and lagoons on the sand sheets where clearing has occurred. These are pasture weeds that have a tolerance for intermittent waterlogging or are annuals that take advantage of suitable areas on the seasonally fluctuating margins of wetlands.

Alien plants have impacted most heavily upon the coastal environment. These plants include ubiquitous species such as Anagallis arvensis, Sonchus spp. and Cirsium vulgare. The most pernicious weeds are Euphorbia paralias and Ammophila arenaria. A arenaria is widespread around the coast on sandy beaches. On Ainslie Beach it forms a continuous band only a few metres wide excluding Spinifex sericeus. The only native grass not displaced by $A$. arenaria is Austrofestuca littoralis. Euphorbia paralias occurs around the entire coast and appears to have become firmly established on the cobble and broken rocky shores especially in the west. During this survey the central western shore

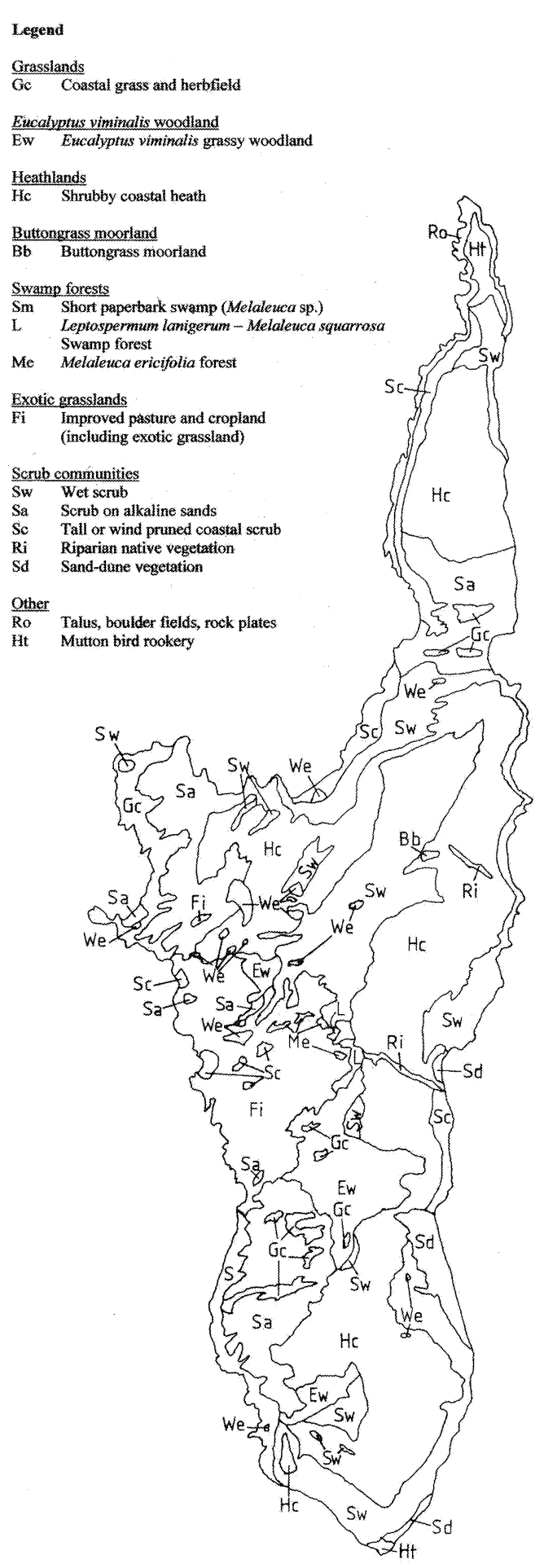

FIG. 5 - Vegetation of Hunter Island.

was examined for $E$. paralias from the northern end of Little Duck Bay (Welcome 1:100 000 map sheet, grid ref. 074103) to the beach at 074069 (Welcome 1:100 000 map sheet). Euphorbia colonised the strandline wherever there were embayments with cobble or shingle beaches and sandy beaches. Invasion had commenced in the zone beyond the strandline but was confined to a strip corresponding to the limit of cast sea-wrack. Invasion further inland is localised and confined to small areas of unstable soil. The beach 
north of Perigo Point had only occasional specimens of Euphorbia paralias. It appears that once the plants become established on pebbly and cobble shores they are less likely to be dislodged by the sea. Cut and fill processes on the sandy beaches may periodically remove whole sections of infestation, causing the fragments and propagules to be washed up on other sections of the coast. Along the east coast, between Cuvier Bay and the end of Ainslie Beach, there are scattered occurrences along the high watermark on sandy sections with the species strongly invading shingle banks above high watermark. Our population estimate for the $4-\mathrm{km}$ section of the west coast we inspected is 8000 and 3000 for the $6-\mathrm{km}$ section of the east coast.

The homestead has not been continuously occupied for many years and garden plants occur there that are confined to the immediate vicinity of the building. These plants demonstrate their ability to survive human neglect. They include Hydrangea sp. cult. (Saxifrageae), Agapanthus orientalis Leighton (Liliaceae), Aloe L. (Liliaceae), Cordyline australis (Forst.f.) Endl. (Agavaceae) and Canary Island palm Phoenix canariensis Chabaud (Arecaceae). These plants are unlikely to become naturalised on the island.

An 1860 report (cited in Buckby 1989) on the island mentioned the presence of the 'cotton plant' as the reason why sheep do not do well on the island. None of the plants that might fit the description is now known to occur on the island. Indeed, during the Macguire period, large flocks of healthy ewes were run on the island (Tony Macguire, pers. comm., 18 April 2002). Ptilotus sp. (Amaranthaceae), sometimes known as 'cotton bush' and Onopordum acanthium (Asteraceae), which is sometimes called 'cotton thistle', are not likely to have been the plants referred to in 1860. These are neither toxic nor would they have precluded sheep. It is possible that an infestation occurred of Gomphocarpus fruiticosa (Asclepiadaceae), sometimes called 'cotton bush', which is toxic to sheep. This African native is localised in some dry areas of southern Australia, including Flinders Island and Prime Seal Island.

\section{Notes on the Macrofungi}

The Tremellales or 'jelly' fungi were found predominantly on dead wood substrates. Occasionally these fungi inhabit living specimens (Fuhrer 1993), which was the case on Hunter Island where Tremella mesenterica was found fruiting on Eucalyptus viminalis. The species was also associated with dead Banksia marginata stems.

The Panaeolus and Poronia species recorded from Hunter Island are coprophilous fungi that occupy a very specific niche by fruiting on dung substrates. It is interesting that Poronia is an obligate coprophile. However, the Panaeolus genus exhibits a terrestrial habitat also. The Poronia species was found growing on cow manure and is also associated with wombat, kangaroo and rabbit dung (Fuhrer 1993). As previously discussed, the island has been subject to a long history of cattle grazing resulting in an alteration of both non-vascular and vascular flora. Cattle provide an excellent means of dispersing fungal spores, particularly on a small island. However, the ramifications of such dispersal are unknown.

In the modified vegetation, the common field mushroom, Agaricus campestris, was located under Cupressus macrocarpa. Lepista nuda was found in the same habitat. Early European records in Australia indicate that Lepista nuda grew primarily with conifers. However, today this species has formed substantial associations with many native species, particularly eucalypts (Fuhrer 1993).

Some fungi located on Hunter Island were tough and leathery, hence more tolerant of drier conditions. Examples of these fungi are listed in appendix 2 under the order Aphyllophorales (see species assigned *). The requirement for water in these species is considerably lower than for the jelly fungi, conferring on them a strong competitive advantage in areas subject to drought. The ability to withstand desiccation has allowed these species to persist in most vegetation communities on the island.

Amanita xanthocephala is a Fungimap species that was recorded only from the relatively dry native grassy woodland.

We frequently observed Omphalina and Hygrocybe species in the extensive heath on Hunter Island. An Amanita sp. was recorded twice on Hunter Island, each time in poorlydrained acidic soil.

Omphalotus nidiformis, or the ghost fungus as it is commonly known, was found on a burnt Banksia marginata stump. This fungus, possessing luminescent properties, is often strongly associated with Eucalyptus species (Fuhrer 1993). Daldinia concentrica was also collected from burnt $B$. marginata stems. This species is commonly located in burnt habitat, with fruiting body production possibly stimulated by fire (Bougher \& Syme 1998, Courtecuisse \& Duhem 1995).

It is difficult to assess which fungi are introduced. The main reasons are sketchy Australian historical accounts, a poor fossil record and the limitations of incomplete taxonomy for many of the major macrofungal groups. Compounding these difficulties is the likelihood that Australian native species have themselves been introduced to other parts of the world (Australian Biological Resources Study 1996). The identity of vascular plant associates is not a reliable guide to the origin of fungi. However, a working assumption is that those species growing in relatively undisturbed (by humans and feral animals) environments are native. Some examples include Amanita xanthocephela, Omphalotus nidiformis, Pycnoporus coccineus, Heterotexus peziziformis and Tremella mesenterica. The most notorious introduced species is Amanita muscaria (fly agaric), with suspected introductions such as Lepista nuda and some of the Agaricus species commonly found in association with exotic plant species, such as Cupressus macrocarpa and Pinus radiata.

We recognise that a more thorough survey would have yielded a larger species list. The absence of ecological literature on Tasmanian macrofungi also impedes a comparison of the species recorded from Hunter Island with those from other regions around the state. However, in establishing a base of mycological information for Hunter Island, we are providing a foundation for further studies.

\section{Chromista}

Symptoms consistent with Phytophthora cinnamomiinfection were observed on the island alongside the track from Ainslie Beach (Homestead Track) and were subsequently confirmed by laboratory isolations from soil samples. The heathy areas over the remainder of the island are very floriferous. Away from the Homestead Track samples taken from dead Phytophthora-susceptible plants on the sides of other tracks all returned negative readings. Soil samples taken from soil 
at the base of dying Banksia marginata shrubs did not test positive for $P$. cinnamomi but indicated an unidentified species of Phytophthora.

Schahinger (2001), on the basis of our observations on the apparent limited occurrence of $P$. cinnamomi, has recommended Hunter Island as a management zone (see appendix 3) for the protection of vulnerable heathland communities from Phytophthora cinnamomi infection. We do not know the age of the $P$. cinnamomi infection but the existing management regime on the island has most likely delayed its incursion.

\section{GENERAL DISCUSSION}

The long history of human use of the island is especially well-documented for the past 200 years. The most significant change to the vegetation since the migration of humans to this area thousands of years ago has probably been the deliberate and accidental introduction of exotic plant species during the relatively short European period. Whereas many of these are both localised and ineffective dispersers or are benign in their effect on native vegetation, some pernicious weeds are present, such as Lycium ferocissimum, which is currently very localised and scarce on the island, and Euphorbia paralias, which is infesting the shoreline. David Steane noted Euphorbia paralias in Tasmania as early as the 1970s at Waterhouse Point; it has since become a major weed of northern Tasmanian coasts and is still spreading. Mutton-bird rookeries are highly prone to weed colonisation.

The most ancient effect of humans on the vegetation of Hunter Island has been the use of fire. It is clear from records at the time of European contact that the Aboriginal population burned the island frequently. There may have been a lull in burning for a few decades between settlement by the sealers and the establishment of a grazing enterprise on the island. Perhaps Robinson's (cited in Plomley 1966) report of 18 June 1830 indicated the commencement of vegetation thickening on the eastern side of the island, where some components of the heath and shrubland will succeed to scrub in the absence of fire: "Crossed over the island to the west side where the sealers have their huts, a distance of about three miles. The travelling across was very bad, through thick forest of tea-tree ... The best part is on the west side and here there is a range of grassy hills". How the fire regime on the island has affected the composition of the flora is uncertain but obligate seeders would tend to become scarce if the frequency was higher than they could cope with. Gunn collected Gompholobium huegelii (an obligate seeder in heaths) in 1837 but we did not observe it during our fieldwork.

The decrease in fire frequency over the island from 1968 to the present is apparent from aerial photographs. In the earliest photographs, the texture of the vegetation indicates a uniformly high fire frequency over the entire island. Only tiny pockets of scrub and forest appear to have a lower frequency where they occur in protected sites alongside cliffs (pl. 9). Overall, the impression is of more extensive heathland than presently exists, with the geological and geomorphological features of the island being much more obvious. The tracks and boundaries of particular fires are also clearly visible in aerial photographs of 1968, 1980 and 2000. The dominant directions represent the prevailing wind directions (pl. 10) - their orientations are clustered around two directions, $25^{\circ}$ and $70^{\circ}$ indicating fires driven

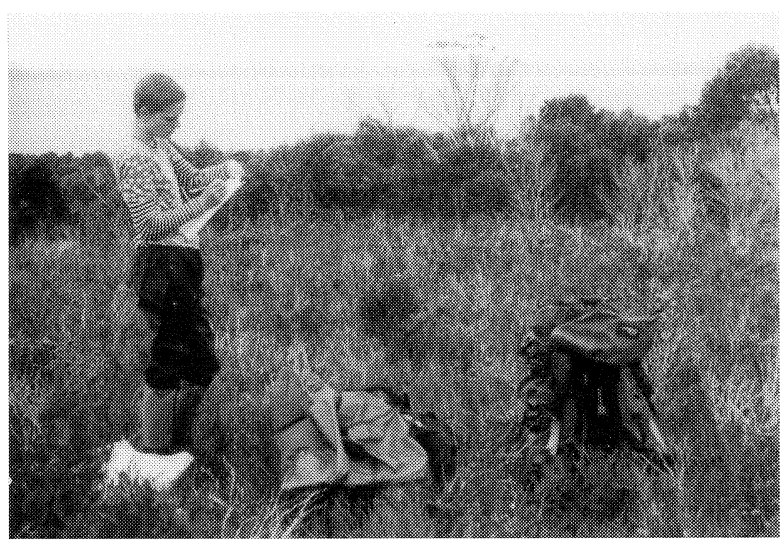

\section{PLATE 10}

A fire boundary on the quartzite plateau between heath less than three years old and tall heath/scrub burnt years ago. The boundary is sharp because fires are usually driven by strong winds that cause burn scars to be linear.

by westerly winds. The palaeo-wind directions during the Pleistocene, when the calcareous sand dunes were blown onto the island, appear to be between $50^{\circ}$ and $62^{\circ}$. The pattern of some fire scars is influenced by the quartzite structural lineaments that run more or less north-south. Fire scars are often abbreviated or deflected by the quartzite.

Many vegetation boundaries on the island are therefore sharp because of the effect of repeated fires reinforcing topographical features as fire boundaries. The boundaries appear much more pronounced in the 1968 photographs than in the 2000 photographs.

In 1968 almost the complete extent of the calcareous dunes were open and grassy with some areas of open grassy shrubland. Recent aerial photographs from 2001 indicate a shift from this open vegetation type to one of denser cover. On the quartzite, heathland was much more extensive in 1968. However, change in the fire regime has led to the formation of scrub in many areas. The open grassy shrubland has thickened in many places, an example being the development of a substantial Eucalyptus viminalis forest with a shrubby component near the limit of a sand sheet north-west of the main airstrip (pl. 6). The most spectacular changes, resulting from a fire regime characterised by longer fire intervals, are visible on the calcareous sands where the post-fire return time for vegetation is likely to be faster due to better fertility and moisture availability compared with the less fertile quartzites. Other notable modifications include the considerable development of scrub behind the first small beach to the west of Cape Cuvier, despite the area having been recently burnt. A comparison between aerial photographs from 1980 and 2001 identified an increase in fringing scrub or forest in many of the island's wetland sites.

The nature of some vegetation boundary transitions and structural profiles is shown in figures 2 and 4.

Palynological evidence supports the change from cold steppe grassland in the Pleistocene to the open shrubland that persisted throughout the Holocene. Human occupation has been attended by a firing pattern about which we know little. It was probably characterised by high frequency. Much of the vegetation is potentially capable of attaining forest stature with a fire-free interval of more than $100-$ 150 years. Small parts of the island have escaped intense 
fires over such a period and some pockets of forest occur on the island. Most of the vegetation has probably oscillated between heathland, open shrubland and scrub during the Holocene. The decrease in frequency in the last 30 years has caused an overall thickening of the vegetation. We suggest that this is within the amplitude of changes that have probably existed for many millennia.

The 1968 data indicate that the Pterostylis cucullata habitat on a dune northwest of the homestead was unfenced and heavily grazed. However, the situation changed approximately 20 years ago when fencing was constructed to ensure that cattle did not disturb the orchids. Some fences have broken down and cattle occasionally roam into areas where orchids grow.

In October 2001 it was evident that the dieback of Eucalyptus nitida and Banksia marginata around the tops of cliffs and bluffs, where soil is shallowest, had resulted from previous dry seasons. Some lag time would be expected for wilting point to be reached in sclerophyllous plants. On 4 and 5 June 2002 some further observations could be made on the island. Following an unusually wet spring and summer, drought mortality was striking. On the west coast a series of low rocky rises all stood out because of the dead plants, mainly young Banksia marginata, Leucopogon sp., Pultenaea daphnoides and Melaleuca ericifolia. Additionally, the extent of quartzite outcrops and cliffs on the east coast were now clearly outlined by the pale brown of the dieback. Periods of low rainfall are more likely to be lethal to plants in a place like Hunter Island where strong and persistent maritime winds dump high salt loads.

Floristic comparisons of the quartzite flora with other areas studied in northwest Tasmania indicate that Hunter Island is an impoverished version of the flora at Mt Cameron West Aboriginal Site (Brown 1980) and at Ordnance Point (Cameron 1984). Similar alkaline sand sheets may be rare on the mainland of northwestern Tasmania. However, the extensive dune systems in the northwest are very calcareous due to the spectacularly large volumes of shells. The island has Eucalyptus viminalis forest on calcareous sands with high surface $\mathrm{pH}(8)$ in contrast with the situation on other Bass Strait and southern Australian coasts. McCoy \& Parsons (1974) noted that Eucalyptus species that may be widespread on siliceous coastal sands in southern Australia are conspicuously absent from adjacent calcareous coastal sands. Parsons \& Specht (1967) found that seedlings of one such eucalypt species showed severe lime chlorosis when grown on calcareous sand. McCoy \& Parsons point out that $E$. ovata is a non-calcifuge eucalypt that occurs in dune swales, the habitat in which the species has been noted at Lughrata Dunes on Flinders Island. It would be interesting to examine whether there is intraspecific difference between the Hunter Island population and populations on different substrates elsewhere.

Fungi play a vital role in the ecosystem but our lack of knowledge about them continues to hamper an holistic knowledge of communities. Most mycological research is taxonomically oriented and while this is vital, delays conducting ecological studies may result in lost opportunities for an understanding of our vegetation. We advocate the incorporation of fungi inventories in general vegetation surveys at whatever taxonomic level suits the surveyor's skills. Such inventories should be supported by adequate descriptions, photographs and, where possible, herbaria specimens. Reporting of these surveys in an appropriately cautious manner will provide a basis on which to build knowledge of fungal ecology. A useful approach is suggested by the Fungimap initiative (May 2001) where information from 100 target species is catalogued in a database providing valuable information regarding the frequency and distribution of some Australian fungal flora.

Islands have long been recognised as important to science because they are clearly defined areas where the role of different factors in the workings of the natural system might be more easily comprehended. Where such islands have substantial areas of native vegetation and where the impact of humans has been well-documented, they are especially important. Hunter Island fits these criteria. Further work is required to ensure the human uses of the island are compatible with its long-term nature conservation and cultural heritage values.

\section{ACKNOWLEDGEMENTS}

We are indebted to Rick Lawrence, the lessee of the island, for his hospitality and interest in our study and our recommendations. Maurie Fowler and his colleagues from Police Marine Search and Rescue based at Stanley did a magnificent job in landing and evacuating our party from the island under challenging weather conditions. Irynej Skira and David James proved to be amiable companions in sharing our base camp on the island. We thank Mark Holdsworth for collecting the Cordyceps gunnii; and Dennis Morris, Alex Buchanan, David Jones, Hans Wapstra, Sapphire McMullan-Fisher and Genevieve Gates for identifying some of our specimens. Louise Murray searched the collections at the National Herbarium of New South Wales; Cathryn Coles at the National Herbarium of Victoria assisted in a similar way. Mick Ilowski tested the soil samples for the presence of Phytophthora. Bob Parsons of LaTrobe University made valuable comments on the similarities with Victorian coastal vegetation. Jonah Gouldthorpe reviewed the manuscript and made many helpful suggestions.

\section{REFERENCES}

Australian Biological Resources Study, 1996: Fungi of Australia. Volume 1A. Introduction - Classification. Canberra.

Bougher, N. \& Syme, K., 1998: Fungi of Southern Australia. Univ. of Western Australia Press, Nedlands.

BOWDLER, S., 1974: An account of an archaeological reconnaissance of Hunter's Isles, north-west Tasmania, 1973/4. Records of the Queen Victoria Museum (Launceston) 54: 1-22.

BOWdLeR, S., 1980: Hunters and farmers in the Hunter Island: Aboriginal and European land-use of north-west Tasmanian islands in the historical period. Records of the Queen Victoria Museum (Launceston) 70: 1-17.

BowdleR, S., 1984: Hunter Hill, Hunter Island: archaeological investigations of a prehistoric Tasmanian site. Terra Australis 8. Dept. of Prehistory, Research School of Pacific Studies. ANU, Canberra.

Brown, M.J., 1980: The vegetation of Mt Cameron West Aboriginal Site. Papers and Proceedings of the Royal Society of Tasmania 114: 21-34.

Buchanan, A., 2002: A Census of the Vascular Plants of Tasmania and Index to the Student's Flora of Tasmania. http:// www.tmag.tas.gov.au Tasmanian Herbarium.

Bureau of Meteorology, 1996: Report on climatic records for Currie, King Island, Swan Island and Three Hummock 
Island. Tasmania and Antarctica Regional Office, Hobart. File 20/11/32 (98).

Bucкву, P., 1989: Legends of Hunter Island. Foot and Playstead, Launceston.

Buckney R.T. \& Tyler P.A., 1973: Chemistry of Tasmanian inland waters. International Revue der Gesamten Hydrobiologie und Hydrographie 58: 61-78.

Cameron, M., 1984: The vegetation of Ordnance Point, northwestern Tasmania. Records of the Queen Victoria Museum (Launceston) 84: 6-32.

Courtecuisse, R. \& Duhem, B., 1995: Mushrooms and Toadstools of Britain and Europe. Collins Field Guide Series, Paris.

DAVIES, J.B., 1981: A botanical survey of Hunter Island - North west Tasmania. Unpublished report, Botany Department, University of Tasmania.

Flinders, M., 1801: Observations on The Coasts of Van Diemen's Land, on Bass's Strait And Its Islands, And on Part of The Coasts of New South Wales. J. Nicholls, London.

Funrer, B., 1993: Field Companion to Australian Fungi. The Field Naturalists Club of Victoria, Australia.

Gentilli, J., 1972: Australian Climatic Patterns. Nelson, Melbourne.

Harris, S., \& BALMER, J., 1997: The flora and vegetation of Three Hummock Island, western Bass Strait. Papers and Proceedings of the Royal Society of Tasmania 131: 37-56.

Harris, S., Buchanan, A. and Connolly, A., 2001: One Hundred Islands: The Flora of the Outer Furneaux. Department of Primary Industries, Water and Environment, Tasmania.

Harris, S. \& McKenny, H., 1999: Preservation Island, Furneaux Group: two hundred years of vegetation change. Papers and Proceedings of the Royal Society of Tasmania 133(1): 85-101.

Hope, G.S., 1978: The late Pleistocene and Holocene vegetational history of Hunter Island, North-western Tasmania. Australian Journal of Botany 26: 493-514.

Hordern, M., 1989: Mariners are Warned!:John Lort Stokes and H.M.S. Beagle in Australia 1837-1843. MUP, Melbourne.

Jarman, S.J., KantVilas, G. \& Brown, M.J., 1988: Buttongrass moorland in Tasmania. Research Report 2. Tasmanian Forest Research Council, Hobart.

Jennings, D.J. \& Sutherland, F.L., 1971: Unpublished report and map. Cited in: Geology of the Islands of Southwestern Bass Strait. Tasmanian Geological Survey Record 1997/03. Mineral Resources Tasmania.

Kirkpatrick, J.B., 1977: The Disappearing Heath. Tasmanian Conservation Trust, Hobart.

Kirkpatrick, J.B. \& Backhouse, S., 1997: Native Trees of Tasmania. rev. ed., Pandani Press, Tasmania.

Kirkpatrick, J.B. \& Harris, S., 1995: The Conservation of Tasmanian dry coastal vascular plant communities. Wildlife Scientific Report 95/1. Parks and Wildlife Service, Hobart.

KirkPatrick, J.B. \& Harris, S., 1999: The Disappearing Heath Revisited. Tasmanian Environment Centre, Hobart.
KirkPatrick, J.B. \& Harwood, C.E., 1981: The Conservation of Tasmanian Wetland Macrophytic Species and Communities. A report to the Australian Heritage Commission by the Tasmanian Conservation Trust.

KirkPatrick, J.B. \& Harwood, C.E., 1983a: Plant communities of Tasmanian wetlands. Australian Journal of Botany 31: 437-451.

KirkPATRiCK, J.B. \& HarwOOD, C.E., 1983b: The conservation of Tasmanian macrophytic wetland vegetation. Papers and Proceedings of the Royal Society of Tasmania 117: 520.

MAY, T.W., 2001: Documenting the fungal biodiversity of Australasia: from 1800 to 2000 and beyond. Australian Systematic Botany 14: 329-356.

McCoy, A. \& PArsons, R.F., 1974: Lime chlorosis of calcifuges on Australian coastal sands. Flora 163: 37-45.

Mueller-Dombois, D. \& Ellenberg, P., 1974: Aims and Methods of Vegetation Ecology. Wiley, New York.

O'ConNor, S., 1982: Bi-coastal: an interpretation of a Hunter Island midden. In S. Bowdler (Ed.): Coastal Archaeology in Eastern Australia. Dept. of Prehistory, Research School of Pacific Studies, Dept. of Prehistory, ANU, Canberra: $133-140$.

Pannell, J.R., 1992: Swamp Forests of Tasmania, Forestry Commission, Tasmania.

Parsons, R.F. \& SPECht, R.L, 1967: Lime chlorosis and other factors affecting the distribution of Eucalyptus on coastal sands in southern Australia. Australian Journal of Botany 15: $95-105$.

Peter, J.M., 2000: Birds and boxthorn. The Victorian Naturalist 117(2): 63-66.

Plomley, N.J.B., 1966: Friendly Mission: The Tasmanian Journals and Papers of George Augustus Robinson 1829-1834. Tasmanian Historical Research Association, Hobart.

Rankin, D.J.W., 1998: Patterns of variation and relationships in the peppermint eucalypts (Eucalyptus L'Her. Ser. Radiatae Chippendale). Unpublished $\mathrm{PhD}$ thesis, LaTrobe University, Melbourne.

Robin, J. \& PARsons, R.F., 1976: The vegetation of Sandy Point, Westernport Bay, Victoria. Royal Society of Victoria Proceedings 88: 83-94.

SCHAhinger, R., 2001: Conservation of Tasmanian plant communities threatened by Phytophthora cinnamomi: Strategic regional plan for Tasmania. Department of Primary Industries, Water and Environment, draft, Nov. 2001.

Scott, G., Entwisle, T., May, T. \& Stevens, N., 1997: A Conservation Overview of Australian Non-Marine Lichens, Bryophytes, Algae and Fungi. Wildlife Australia, Endangered Species Program.

Williams, K. J. \& PotTs, B.M., 1996: The natural distribution of Eucalyptus species in Tasmania. Tasforests 8: 39-65.

(accepted 9 December 2002) 


\section{APPENDIX 1}

Higher plant census for Hunter Island

Nomenclature follows Buchanan (2002) except for some orchids, which follow Jones et al.1999.

$\mathrm{i}=$ introduced in Tasmania.

(i) = formerly extinct on Hunter Island, new introduction.

$\mathrm{e}=$ endemic in Tasmania.

ws = wetland survey conducted by Kirkpatrick \& Harwood (1981).

$\mathrm{tbm}=$ recorded by T. Bruce Muir, National Herbarium of Victoria. Plants found around the central part of the island in November 1973 ,

from an unpublished checklist.

\section{DICOTYLEDONAE}

AIZOACEAE

Carpobrotus rossii

Disphyma crassifolium

Tetragonia implexicoma

\section{APIACEAE}

Apium prostratum

Daucus glochidiatus

Hydrocotyle hirta

H. muscosa ws

$H$. pterocarpa ws

H. sibthorpioides

Lilaeopsis polyantha ws

Xanthosia dissecta

APOCYNACEAE

Alyxia buxifolia

ASTERACEAE

Actites megalocarpa tbm

Ammobium calyceroides e

Arctotheca calendula i

Apalochlamys spectabilis

Bellis perennis i

Chrysocephalum apiculatum tbm

Cirsium vulgare $\mathrm{i}$

Cotula coronopifolia

C. vulgaris var. australasica

Craspedia sp.

Cymbonotus preissianus

Gnaphalium indutum

Hypochoeris glabra i

$H$. radicata i

Lagenophora sp.

Leontodon taraxacoides i

Leucophyta brownii

Olearia glutinosa

O. lepidophylla

O. ramulosa

Ozothamnus turbinatus

Senecio biserratus

S. pinnatifolius

Sonchus oleraceus i

S. asper i

Pseudognaphalium luteo-album

Vellereophyton dealbatum $\mathrm{i}$

BRASSICACEAE

Cakile maritima i

Cardamine gunnii ws

Lepidium desvauxii

Rorippa nasturtium-aquaticum $\mathrm{i}$

CALLITRICHACEAE

Callitriche stagnalis $\mathrm{i}$

CAMPANULACEAE

Lobelia anceps

Pratia irrigua ws

Wablenbergia sp.
CAPRIFOLIACEAE

Sambucus gaudichaudiana

CARYOPHYLLACEAE

Cerastium glomeratum $\mathrm{i}$

Colobanthus apetalus var. apetalus

Minuartia mediterranea i

Polycarpon tetraphyllum i

Sagina maritima i

Silene gallica tbm (i)

Stellaria media $\mathrm{i}$

CASUARINACEAE

Allocasuarina monilifera

CHENOPODIACEAE

A. billardierei

A. cinerea $i$

A. hastata

Chenopodium glaucum i?

Rhagodia candolleana subsp. candolleana

Sarcocornia quinqueflora

CONVOLVULACEAE

Convolvulus erubescens tbm

Dichondra repens

CRASSULACEAE

Crassula decumbens

C. helmsii ws

C. sieberiana subsp. sieberiana

C. sieberiana subsp. tetramera

CUNONIACEAE

Bauera rubioides

DILLENIACEAE

Hibbertia prostrata tbm

$H$. procumbens

H. sericea

DROSERACEAE

Drosera peltata subsp. auriculata

D. pygmaea

EPACRIDACEAE

Astroloma humifusum

A. pinifolium

Epacris impressa

E. lanuginosa

Leptecophylla juniperina subsp. parvifolia

Leucopogon australis

L. collinus

L. ericoides

Monotoca glauca

Sprengelia incarnata

EUPHORBIACEAE

Amperea xiphoclada

Euphorbia paralias i

E. peplus i

Phyllanthus gunnii

Poranthera microphylla

FABACEAE

Aotus ericoides 
Dillwynia glaberrima

Goodia lotifolia

Kennedia prostrata

Melilotus indicus i

Persoonia juniperina

Phyllanthus gunnii

Phyllota diffusa e

Pultenaea daphnoides var. obcordata

$P$. dentata

Swainsona lessertiifolia

Trifolium repens $\mathrm{i}$

T. subterraneum $\mathrm{tbm} \mathrm{i}$

FUMARIACEAE

Fumaria muralis $\mathrm{i}$

GENTIANACEAE

Centaurium erythraea $\mathrm{i}$

Sebaea albidiflora

Sebaea ovata

GERANIACEAE

Erodium sp. i

Geranium potentilloides

$G$. rotundifolium i

G. solanderi

Pelargonium australe

P. $\mathrm{x}$. domesticum $\mathrm{i}$

GOODENIACEAE

Selliera radicans

HALORAGACEAE

Gonocarpus teucrioides

Gonocarpus tetragynus

Myriophyllum amphibium ws

LAMIACEAE

Ajuga australis

Marrubium vulgare $\mathrm{i}$

Mentha diemenica var. serpyllifolia.

LAURACEAE

Cassytha glabella

C. pubescens

LEMNACEAE

Lemna minor

LENTIBULARIACEAE

Utricularia dichotoma $\mathrm{tbm}$

MALVACEAE

Malva sylvestris $\mathrm{i}$

MENYATHACEAE

Villarsia reniformis

MIMOSACEAE

Acacia myrtifolia

A. mucronata

A. suaveolens

A. verticillata subsp. ovoidea

A. verticillata subsp. verticillata

A. longifolia var. sophorae

MYOPORACEAE

Myoporum insulare

MYRTACEAE

Calytrix tetragona

Eucalyptus nitida e

E.obliqua

E. ovata

E. viminalis

Leptospermum glaucescens $\mathrm{e}$

L. laevigatum

L. lanigerum

L. scoparium

Melaleuca ericifolia

Melaleuca squamea
Melaleuca squarrosa

OLEACEAE

Ligustrum vulgare $\mathrm{i}$

ONAGRACEAE

Epilobium billardierianum

E. sarmentaceum

OXALIDACEAE

Oxalis perennans

PITTOSPORACEAE

Bursaria spinosa

PLANTAGINACEAE

Plantago coronopus i

P. lanceolata tbm i

P. major i

P. varia $\mathrm{tbm}$ i

POLYGALACEAE

Acetosella vulgaris $\mathrm{i}$

Comesperma calymega

C. retusum

C. volubile

Muehlenbeckia adpressa

PORTULACEAE

Calandrinia calyptrata

PRIMULACEAE

Anagallis arvensis $\mathrm{i}$

Samolus repens

PROTEACEAE

Banksia marginata

Persoonia juniperina

RANUNCULACEAE

Ranunculus amphitrichus

$R$. repens $\mathrm{i}$

R. muricatus

RHAMNACEAE

Pomaderris apetala subsp. apetala

$P$. apetala subsp. maritima

ROSACEAE

Acaena pallida

A. novae-zelandiae

Prunussp. i

RUBIACEAE

Coprosma repens $\mathrm{i}$

Galium australe

Galium murale i

Rosa sp. $i$

RUTACEAE

Boronia anemonifolia

B. citriodora

B. parviflora

Correa alba

C. backhouseana

C. lawrenceana?

SALICACEAE

Salix cinerea i

SCROPHULARIACEAE

Linaria vulgaris $\mathrm{i}$

Limosella australis ws

Mazus pumilio

SOLANACEAE

Lycium ferocissimum $\mathrm{i}$

STACKHOUSIACEAE Stackhousia spathulata

STYLIDIACEAE Stylidium graminifolium

THYMELAEACEAE

Pimelea drupacea 
Pimelea linifolia

\section{URTICACEAE}

Parietaria debilis

Urtica incisa

VIOLACEAE

Viola hederacea

\section{MONOCOTYLEDONAE}

ARACEAE

Zantedeschia aethiopica i

CENTROLEPIDACEAE

Centrolepis strigosa

CYPERACEAE

Baumea acuta

B. arthrophylla ws

B. juncea

Carex appressa

C. breviculmis

C. fascicularis ws

Gahnia grandis

G. trifida

Gymnoschoenus sphaerocephalus

Isolepis cernua ws

I. fluitans ws

I. inundata ws

I. nodosa

I. subtilissima

Lepidosperma concavum

L. elatius

L. gladiatum

Schoenus maschalinus

S. nitens ws

S. lepidosperma subsp. lepidosperma

Tetraria capillaris

IRIDACEAE

Patersonia fragilis

JUNCACEAE

Juncus articulatus ws

J. caespiticius ws

$J$. holoschoenus ws

J. kraussii ws

J. pallidus

J. pauciflorus

$J$ planifolius ws

J. procerus ws

Luzula campestris

JUNCAGINACEAE

Triglochin striatum ws

Triglochin procerum ws

LILIACEAE

Allium sp. i

Dianella revoluta

D. tasmanica

Thelionema caespitosa

ORCHIDACEAE

Burnettia cuneata tbm

Caladenia carnea

C. latifolia

Calochilus herbaceous

C. paludosus tbm

Cyrtostylis reniformis tbm

C. robusta

Microtis parviflora tbm

M. unifolia tbm+

Pterostylis cucullata

$P$. pedunculata tbm

P. nutans

Pyrorchis nigricans
Thelymitra aristata tbm

T. cyanea

T. ixioides

T. pauciflora

POACEAE

Agrostis avenacea ws

Aira caryophyllea i

Ammophila arenaria $\mathrm{i}$

Anthoxanthum odoratum tbm i

Austrostipa flavescens

Austrostipa stipoides

Briza minor tbm i

Bromus diandrus i

Bromus hordeaceus i

Catapodium marinum i

Dactylis glomerata i

Dichelachne crinita

Distichlis distichophylla

Ehrharta sp.

Holcus lanatus i

Hordeum murinum i

Lolium sp.? i

Notodanthonia semiannularis ws

Parapholis incurva i

Pennisetum clandestinum $\mathrm{i}$

Poa annua i

Poa poiformis var. poiformis

Poa sieberiana

Spinifex sericeus

Triticum sp. i

Vulpia megalura $\mathrm{i}$

POTAMOGETONACEAE

Potamogeton australiensis ws

RESTIONACEAE

Apodasmia brownii

Baloskion tetraphyllum ws

Empodisma minus

Eurychorda complanata

Hypolaena fastigiata

Lepyrodia tasmanica

Sporadanthus tasmanicus

XYRIDACEAE

Xyris marginata

GYMNOSPERMAE

CUPRESSACEAE

Cupressus macrocarpa $\mathrm{i}$

PTERIDOPHYTA

ASPLENIACEAE

Asplenium obtusatum

BLECHNACEAE

Blechnum wattsii

DENNSTAEDTIACEAE

Pteridium esculentum

DICKSONIACEAE

Dicksonia antarctica

LINDSAEACEAE

Lindsaea linearis

POLYPODIACEAE

Microsorum pustulatum subsp. pustulatum

SCHIZAEACEAE

Schizaea bifida

SELAGINELLACEAE

Selaginella uliginosa 
APPENDIX 2

Non-vascular census for Hunter Island

\section{MACROFUNGI}

Nomenclature follows Fungi of Australia Volume 1A (1996).

$\mathrm{F}=$ Fungimap species as targeted by the National Herbarium of Victoria.

$\mathrm{W}=$ widely distributed on Hunter Island.

$\mathrm{R}=$ observed once only on Hunter Island.

$\mathrm{IH}=$ identified twice or more in specific habitats on Hunter Island.

\section{BASIDIOMYCOTA}

AGARICALES

Agaricus campestris $\mathrm{R}$

Amanita xanthocephala LC F

Amanita sp. IH

Coprinus sp. (aff. micaceus) $\mathrm{R}$

Hygrocybe spp. (1=red; $1=$ orange-red) $\mathrm{IH}$

Lepista nuda R F

Mycena viscidiocruenta $\mathrm{R} \mathrm{F}$

Omphalina cromacea or ericetorum W F

Omphallotis nidiformis R F

Panaeolus sp. IH

APHYLLOPHORALES

Clavulinopsis sp. (brilliant orange aff. miniata) R

Coltricia obtectans *W

Ganoderma sp. (uncertain identification) *R

Polyporus arcularius ${ }^{*} \mathrm{IH}$

Pycnoporus coccineus *W

Stereum ostrea ${ }^{*} \mathrm{IH} \mathrm{F}$

Stereum spp. ${ }^{*} W$

BOLETALES

sp. from Boletales $\mathrm{R}$

DACRYMYCETALES

Calocera sp. IH

LYCOPERDALES

Lycoperdon sp. W

\section{TREMELLALES}

Heterotexus peziziformis $\mathrm{R}$

Tremella mesenterica IH F

SCLERODERMATALES

Scleroderma sp. IH

\section{ASCOMYCOTA}

CLAVICIPITALES

Cordyceps gunnii $\mathrm{R}$

XYLARIALES

Poronia erici or punctata R F

Black Cup fungi W

MYXOMYCOTA

Small red slime mould (Fuligo?) R

\section{LICHENS}

All lichen species held at the Royal Botanic Gardens Victoria

CLADIACEAE

Cladia aggregata

Cladia retipora

CLADONIACEAE

Cladonia cervicornis ssp. verticillata

PARMELIACEAE

Flavoparmelia haysomii

PHYSCIACEAE

Rinodina blastidiato

TELOSHISTACEAE

Caloplaca sublobulata

Teloschistes chrysophthalmus

Teloschistes spinosus

Xanthoria ligulata 
APPENDIX 3

Management recommendations in order of priority

These management recommendations are subject to negotiation with the lessee of the island and are listed here as a basis for discussion.

\section{Fire management}

A fire management plan should be prepared for the island, recognising that the current flora and vegetation have survived a very high fire frequency. A plan is required that:

1. Sets appropriate burning frequencies for heath and scrub.

2. Specifies measures for asset protection from fire.

3. Allows for protection from fires of some vegetation types.

4. Allows for research on fire regimes and plant and animal responses.

\section{Feral animals}

Confinement of cattle to fenced areas on the central grasslands will assist recovery of some coastal vegetation and wetland margins. The cost of fencing improvements could be offset by the sale of the feral cattle.

\section{Ecosystem threats}

The island should be considered as a Phytophthora cinnamomi management area and monitored for spread of disease symptoms.

\section{Threatened species}

Further surveys and habitat information should be collected for Pterostylis cucullata and management actions for the species should be implemented. These actions will act as part of a general recovery plan for the species.
The lessee should be advised of locations of other species of conservation significance and further opportunities taken to define the species extent and condition.

\section{Weeds}

Boxthorn (Lycium ferocissimum) should be removed from the vicinity of both the homestead and Cape Keraudren as a priority. The species is very invasive, as birds will transport it to other islands and rookeries (Peter 2000).

Sea spurge (Euphorbia paralias) should be subject to a concerted eradication/control program on the island as resources allow. These infestations will provide seed for continual dispersal to the north and west coasts of the Tasmanian mainland.

\section{General}

The above recommendations should be discussed further with the lessee and considered as part of the lease renewal conditions and a management plan for the Fleurieu Group or for the island.

The Nature Conservation Branch, DPIWE, has identified the island as a suitable site for a field research station. Such a station would be of assistance in carrying out some of the above recommendations. 